\title{
The comparative toxicity of two Canadian diluted bitumens to developing yellow perch (Perca flavescens)
}

\author{
DENBY McDONNELL \\ Co-supervisors: Dr. Valerie Langlois \& Dr. Barry Madison \\ Examiner: Dr. Peter Hodson
}

Thesis submitted in partial fulfillment of the requirements for B. Sc. (Honours)

School of Environmental Studies

Queen's University, Kingston, ON

April 2017 


\begin{abstract}
Increasing demand for diluted bitumen (dilbit) has led to the development of the Alberta oil sands industry and the expansion of current and future transcontinental pipelines. However, the growth of oil transportation has led to public concern about the effects of potential dilbit spills to aquatic ecosystems. Because dilbit is an unresolved complex mixture (UCM) with variable diluent and bitumen composition, its toxic effects are little known. Thus, it is important to understand the effects of the two most transported dilbits in Canada, Access Western Blend (AWB) and Cold Lake Blend (CLB). We compared the toxicity of AWB and CLB to yellow perch (Perca flavescens), a species present throughout North America. Embryos were exposed to dilbit for 16 days, from $<24$ hours post-fertilization until hatch. The treatment regime was a static daily renewal of water accommodated fractions (WAF) and chemically-enhanced water accommodated fractions (CEWAF) at concentration ranges of 0.02 to $11 \mu \mathrm{g} / \mathrm{L}$ and 0.21 to 20 $\mu \mathrm{g} / \mathrm{L}$ total polycyclic aromatic hydrocarbons (TPAH), respectively. Hatched embryos were assessed for malformations and preserved at $-80{ }^{\circ} \mathrm{C}$ for analysis of gene expression associated with phase I and II detoxification, cellular stress, and xenobiotic metabolism. Results show that with increased TPAH concentration, the frequency of hatched embryos with developmental malformations increased proportionally. The highest concentration of AWB WAF caused a high rate of mortality. As well, WAF treatments caused a higher prevalence of malformations than CEWAF. These preliminary results were unexpected because previous studies demonstrated a greater toxicity of CEWAF. Relative mRNA of cypla showed induction up to 18 -fold in WAF and 50-fold in CEWAF treatments, and AWB had lower EC50s than CLB. This is the first study assessing the toxicity of both AWB and CLB dilbits on wild-sourced fish. With recent approvals of pipelines in North America, these biomarkers will assist risk assessments and monitoring of Canadian ecosystems should a pipeline spill occur.
\end{abstract}




\section{ACKNOWLEDGEMENTS}

I would like to thank my supervisors Dr. Valerie Langlois and Dr. Barry Madison for allowing me this opportunity. To Dr. Langlois, I am inspired by your dedication to your lab. Thank you for this invaluable experience, your continuous feedback, and for always motivating me to put forth my best effort. Dr. Madison, thank you for always being there to respond to my numerous questions or to spend hours explaining concepts to me. Your passion for your work encourages me to be more meticulous and to strive for quality.

Thank you to my committee member, Dr. Hodson, for having a positive face in a crowd, and for guiding me on the convolutions of oil. I am grateful for your exceptional editing skills.

This project could not have been completed without the fantastic Sarah Wallace. Thank you for your dedication in everything that you do. From the exposure, to optimizing primers, to guiding me through every step in the lab, I am forever grateful. I would also like to thank Chrissie Emerton for leading the exposure procedures. Thank you to Tash-Lynn Colson for conducting DNase treatments and Melody Kang for her work on the exposure and for keeping me company during hours of malformation assessment.

This work was funded by the National Contaminant Advisory Group (NCAG) of Fisheries and Oceans Canada to Dr. Valerie Langlois and Dr. Peter V. Hodson, and by a Canada Research Chair (CRC) to Dr. Valerie Langlois. 
Table of Contents

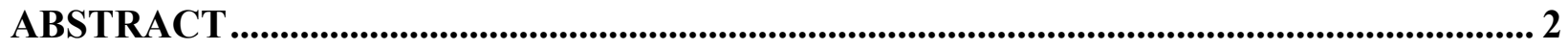

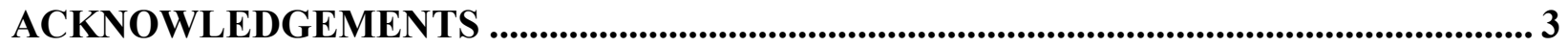

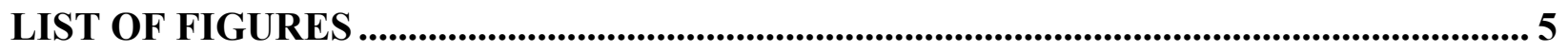

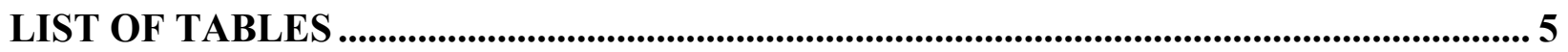

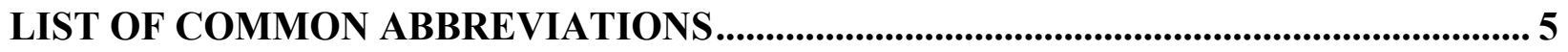

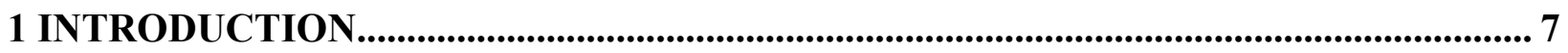

1.1 Production and transport of diluted bitumen in Canada ............................................... 7

1.2 Chemical properties, physical properties, and weathering of diluted bitumen ....................... 8

1.3 Oil polycyclic aromatic hydrocarbons (PAHs) and embryotoxicity ...................................... 11

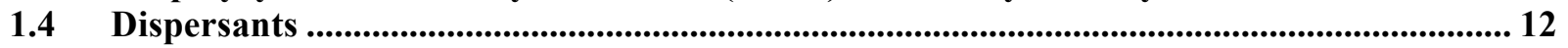

1.5 Effects of oil exposure on phase I detoxification and xenobiotic metabolic stress............... 13

1.6 Effects of oil exposure on cellular stress and phase II detoxification ..................................... 15

1.7 Yellow Perch (Perca flavescens) life history and ecology ........................................................... 17

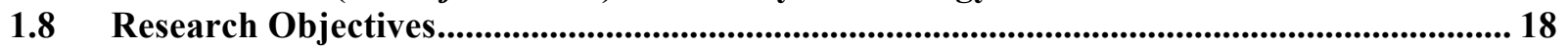

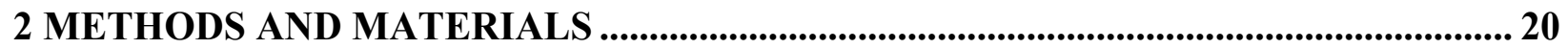

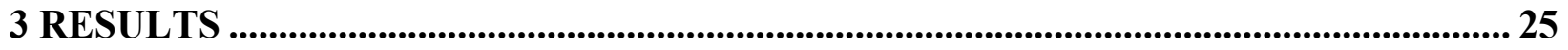

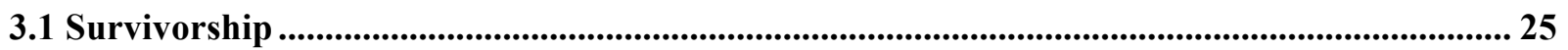

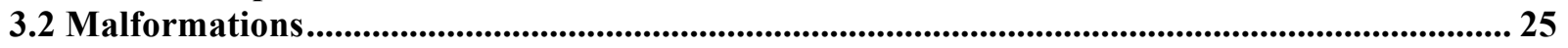

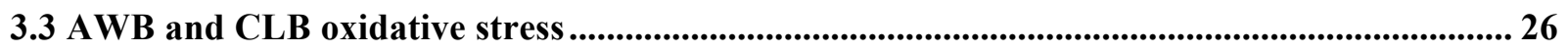

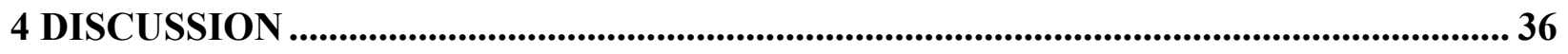

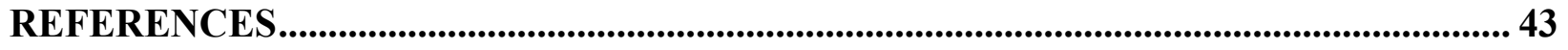

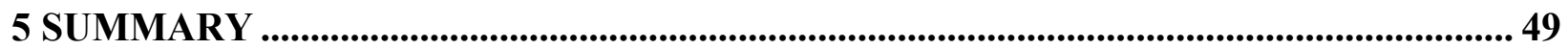

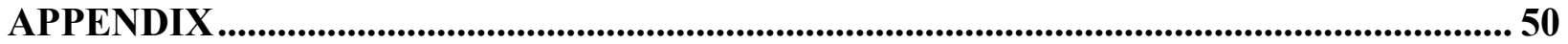




\section{LIST OF FIGURES}

Figure 1. Mechanisms of PAH toxicity in the cell.

Figure 2. \% Affected yellow perch embryos and log TPAHs.

Figure 3. Relative mRNA levels to the housekeeping genes of cypla, cat, gsr, and ahr.

Figure 4. Relative mRNA levels to the housekeeping genes of sod and p53.

\section{LIST OF TABLES}

Table 1. Genes of interest, biological function, and primer conditions.

Table 2. \% Hatch success and \% affected.

Table 3. Frequency index of developmental malformations at hatch.

Table 4. Summary of the significant changes in gene expression.

Table 5. Regressions of responses to dilbit exposure in genes of interest.

\section{LIST OF COMMON ABBREVIATIONS}

AhR: Aryl hydrocarbon receptor

AWB: Access Western Blend

CLB: Cold Lake Blend

CAT: Catalase

CEWAF: Chemically enhanced water accommodated fraction

CYP1A: Cytochrome P450

DC: Dispersant control

EF1A: Elongation factor 1-alpha

GC-MS: Gas-Chromatography-Mass Spectrometry

GSR: Glutathione Reductase

P53: Tumour protein P53

PAH: Polycyclic aromatic hydrocarbon

SOD: Superoxide dismutase 1, soluble 
ROS: Reactive oxygen species

RPL8: Ribosomal protein L8

TPAH: Total polycyclic aromatic hydrocarbon

UCM: Unresolved complex mixtures

WAF: Water accommodated fraction 


\section{INTRODUCTION}

\subsection{Production and transport of diluted bitumen in Canada}

Diluted bitumen (dilbit) is a significant commodity for Alberta, Canada, and the

Canadian economy. The Alberta oil sands are the third largest oil source in the world where most oil is extracted from three main deposits: Peace River, Athabasca, and Cold Lake (Alberta Energy 2011; CAPP 2014). Oil extracted from the Alberta oil sands is bituminous and is diluted to produce dilbit. Two Canadian dilbits, Access Western Blend (AWB) from Athabasca and Cold Lake Blend (CLB) from Cold Lake are the highest volume oil sands products transported in Canada (GOC 2013). There is an estimated 171 billion barrels of oil reserved in Canada; 166.3 billion barrels are found in Alberta's oil sands and 4.7 billion barrels are from conventional or offshore oil sources (NRC 2016). Dilbit is known as unconventional oil because it requires intensive processing and additives to become a transportable and usable petroleum product.

Dilbit is an unresolved complex mixture (UCM) of raw bitumen and diluents made of oilgas condensates that control viscosity to facilitate transport through pipelines (Crosby et al. 2013). Furthermore, dilbit composition varies seasonally to maintain flow in different temperatures by altering the ratios of bitumen to diluents (NRC 2013). These qualities make it difficult to study dilbit, as the chemical composition is variable and only known by producers.

Increasing demand to transport dilbit to European and Asian markets has led to the expansion of transcontinental pipelines, which would increase production and transport of dilbit from the Alberta oil sands to ports (CAPP 2014). The expansion of pipeline projects in Canada has caused debate over proposals such as the Trans Canada Energy East pipeline from Alberta to New Brunswick, which would transport 1.1 million barrels a day over $4500 \mathrm{~km}$, as well as the recently approved Kinder Morgan Trans Mountain Pipeline expansion from Alberta to 
Abbotsford, B.C., which will increase capacity to 890000 barrels a day over $1150 \mathrm{~km}$ (Kinder Morgan 2016; TransCanada 2016). These pipelines have large economic viability, which makes them a priority for Canadian business development.

However, pipelines in Canada traverse major watersheds, lakes and streams, where an oil spill could result in serious impact to species, resources, and aquatic ecosystems. With the expansion of pipelines in Canada to meet international demands, it is critical to understand the potential impacts a dilbit spill may have on fish species, particularly their sensitive and developing life stages. Understanding patterns of species sensitivity may allow for progressive risk assessments and spill-response plans (Posthuma et al. 2002). However, little is known about the toxicity of dilbit, which is particularly important in freshwater ecosystems where relatively few studies have been performed. The Royal Society of Canada Expert Panel report on the Behaviour and Environmental Impacts on Crude Oil Released into Aqueous Environments identified a number of dilbit research needs, including understanding how different dilbits and dispersants affect aquatic species (Lee et al. 2015).

\subsection{Chemical properties, physical properties, and weathering of diluted bitumen}

Oils vary in composition based on the relative concentrations of the four major classes, including saturates, aromatics, resins and asphaltenes, as well as minor components, such as organometallic compounds or naphthenic acids (Lee et al. 2015). Polycyclic aromatic hydrocarbons (PAHs) are found in crude oil, particularly their alkylated congeners (alkyl PAHs) such as naphthalenes, phenanthrenes, fluorenes, dibenzothiophenes, and chrysenes (Wang et al. 1999). It has been suggested that dilbit has the most variable composition of any transportable oil due to added diluent fractions, which vary between season and location to reach the specifications of $<300 \mathrm{mPa}$ and specific gravity $<0.94$ (Fingas 2015). Bitumen is most 
frequently diluted to a ratio of 70:30 bitumen-to-diluent with lighter oil-gas condensates obtained from natural gas wells, or naphtha (Crosby et al. 2013; Dew et al. 2015). Although total concentration of alkyl PAHs in heavy fuel oil (HFO) are ten times more concentrated than dilbit, volatilization may cause dilbit to have high toxicity because the dissolved dilbit fractions can cross biological membranes (Environment Canada 2006; Dupuis and Ucan-Marin 2015).

The majority of PAHs in raw Alberta oil sands bitumen are alkyl PAHs, where the concentration of $\mathrm{C}_{0^{-}}<\mathrm{C}_{1}-<\mathrm{C}_{2}-<\mathrm{C}_{3}$ for all alkyl PAHs (Yang et al. 2011). In the event of a dilbit spill and environmental exposure, the relative compositions of alkyl PAHs may affect toxicity. Furthermore, CLB has been associated with a high persistence of aromatics and higher quantities of alkyl PAHs compared to AWB (King et al. 2014). Alberta oil sands processing reduces $\mathrm{C}_{1}$ - to $\mathrm{C}_{3}$-naphthalene homologue concentrations that are common in fresh crude oil, then increases the abundance of $\mathrm{C}_{0}$ - to $\mathrm{C}_{3}$-naphthalene isomers due to added diluents (Yang et al. 2011). Due to the complexity of dilbit, research is necessary to confirm its chemical composition and create standardized regulations.

The physical characteristics of dilbit are not well known, variable, and highly debated. Research has suggested that dilbit may sink during weathering; as lighter diluents volatilize upon exposure, the higher molecular weight components of dilbit may be more persistent, causing dilbit to return to a high density (Lee et al. 2015). If weathering causes dilbit to reach a density $>1 \mathrm{~g} / \mathrm{cm}^{3}$, it may precipitate to sediments (Yarranton et al. 2015). The Kalamazoo River dilbit spill of AWB and Canada Western Select dilbits occurred in July 2010 in Michigan, USA, after a pipeline burst (Crosby et al. 2013). This oil spill provided many opportunities to assess the effects of dilbit in aquatic ecosystems. It was reported that $10-20 \%$ of the dilbit sank to the bottom of the river and oil sediment aggregates were found in samples collected from river 
sediments (Lee et al. 2012; US EPA 2013). The physical qualities of dilbit may cause sediment contamination, negatively affecting fish embryos or spawning sites. However, AWB and CLB produced from the Alberta oil sands may float in seawater even after evaporation, exposure to light, and a temperature range of $0-15^{\circ} \mathrm{C}$ (GOC 2013). In a tank experiment, wave-like conditions and current were unable to disperse dilbit (GOC 2013). But, when fine sediment was added into small-seawater vessels with high-energy mixing, dilbit sank or formed floating tarballs (GOC 2013). This experiment raises questions about the physical behaviour of dilbit in freshwater environments, particularly in rivers with high turbidity.

When dilbit is exposed to the environment, the lighter weight diluents and volatile oil-gas condensates begin to weather and volatilize (King et al. 2014). When these lighter and volatile components evaporate, heavier non-volatile components such as tars and resins may sink (King et al. 2014). There are many factors involved in determining if dilbit sinks or floats when interacting with environmental factors, particularly when different oils (e.g., AWB and CLB) have different compositions. Furthermore, biodegradation of alkyl PAHs increases as rings and alkylation decrease. Yang et al. (2011) found that 2-ring alkylated naphthalenes were the first to biodegrade, whereas alkylated 4-ring chrysenes were the slowest to biodegrade. These findings emphasize that $\mathrm{C}_{0}$ biodegrades the most rapidly of alkyl PAH homologues $\mathrm{C}_{0^{-}}<\mathrm{C}_{1^{-}}<\mathrm{C}_{2^{-}}<\mathrm{C}_{3}$, affirming that PAH degradation is inversely proportional to homologue rings (Wang et al. 1998; Yang et al. 2011). The high abundance of alkyl PAHs in dilbit is relevant to determine its weathering behaviour. In both AWB and CLB, the naphthalene alkyl PAH series formed a bell curve due to added diluents, which could be altered during diluent evaporation (GOC 2013). While this study suggested that AWB or CLB dilbit would not sink in marine environments, similar weathering tank studies in salt-water have displayed opposing results (GOC 2013). King 
et al. (2014) found that AWB droplets were capable of sinking in seawater after six days of weathering, while CLB continued to float because of a higher alkyl PAH concentration. Based on the densities achieved from seven days of natural weathering, it is likely that AWB would sink in freshwater environments, and that raw bitumen would sink in seawater with sediment interaction (King et al. 2014). During weathering, AWB may take $16 \mathrm{~h}$ and CLB may take $24 \mathrm{~h}$ to increase to half the density of non-weathered dilbit (King et al. 2014). These effects are temporal because CLB has a higher alkyl-PAH concentration than AWB, causing it to degrade more slowly. Further studies are necessary due to the complicated relationship between dilbit chemical compositions and weathering, which requires a better understanding to enact spillresponse plans.

\subsection{Oil polycyclic aromatic hydrocarbons (PAHs) and embryotoxicity}

Studies on conventional oils have determined that PAHs are the most chronically toxic components of oils (Barron et al. 1999). Developing fish embryos are particularly susceptible to toxicity through exposure to dissolved PAHs (Carls et al. 2008), which occurs through the subsurface weathering of dilbit. Although all components of oil are important to determine weathering behaviour, smaller and more bioavailable compounds are toxic to fishes. Low molecular weight compounds may cause acute toxicity, or narcosis, in fish (Madison et al. 2017). Conversely, 3-5 ringed PAHs separate readily from oil droplets during weathering of conventional oils, increasing bioavailability and embryotoxicity during chronic exposures in fish (Saravanabhavan 2007; Hodson et al. 2007; Bornstein et al. 2014; Adams et al. 2014a). Furthermore, PAHs are known to alter the expression of genes that control phase I and II detoxification and biotransformation (Ramachandran et al. 2004; Fallahtafti et al. 2012; Regoli and Giuliani 2014). 
PAHs are toxic to fish species; however, only four studies have investigated the effects of dilbit on fishes so far (Madison et al. 2015; 2017; Philibert et al. 2016; Alderman et al. 2017). Comparisons of dilbits have found varied concentrations of total PAHs (TPAHs); King et al. (2014) determined that CLB had more TPAHs than AWB, which may cause higher toxicity to developing embryos. An exposure of Japanese medaka (Oryzias latipes) to AWB WAF and CEWAF caused malformations and physiological responses to oxidative stress (Madison et al. 2015). A subsequent exposure of Japanese medaka to AWB WAF and CEWAF found the most common malformations were yolk sac edema, then craniofacial malformation, and then pericardial edema (Madison et al. 2017). Alderman et al. (2017) found that exposing juvenile sockeye salmon (Oncorhynchus nerka) to dilbit caused cardiac remodelling, while the frequency of pericardial malformations increases with PAH exposure (Philibert et al. 2016). However, further study is required to determine the effects of different dilbit blends on native Canadian fish species, particularly those of early life stages in freshwater ecosystems.

\subsection{Dispersants}

In the event of an oil spill, mixtures of solvents and surfactants, known as dispersants, are used to mix oil in water and prevent the formation of oil slicks (Place et al. 2010). Chemical dispersants reduce surface oil and mitigate risk to surface species such as seabirds or marine mammals (Lee et al. 2015). However, dispersants may also increase toxicity to aquatic organisms, which occurs through increased exposure to toxic compounds in oil and to dispersant components (NRC 2005). Kujawinski et al. (2011) assessed the application of Corexit ${ }^{\circledR} 9500 \mathrm{~A}$ dispersant to the Deepwater Horizon oil spill and found that the dispersant remained at depth up to 64 days later and $300 \mathrm{~km}$ from the application site, suggesting slow biodegradation and potential toxicity to aquatic organisms. However, Corexit ${ }^{\circledR} 9500 \mathrm{~A}$ and other dispersants are 
mainly formulated for marine spill use. While the addition of divalent salt has increased the effectiveness of Corexit ${ }^{\circledR} 9500 \mathrm{~A}$ in freshwater, dispersants remain less effective on heavy oils such as dilbit (George-Ares et al. 2001). King et al. (2015) found that CLB was more effectively dispersed with the addition of dispersant and mineral fines, which could control the release of toxic oil components.

It has been suggested that the use of dispersants increases oil toxicity through increased PAH exposure (Lee et al. 2015). However, these effects are not driven by a synergistic interaction between dispersants and oil components (Adams et al. 2014a). Chemically-enhanced water accommodated fractions (CEWAF) are more toxic than mechanically-dispersed oil, or water-accommodated fractions (WAF) and modern dispersants alone (Hemmer et al. 2011). Although dispersants are not intended for freshwater or lower energy systems, they have been used to study Corexit ${ }^{\circledR}$ EC9500A toxicity, to remove the physical effects of viscosity and improve oil mixing with water, and to increase dissolved PAHs for experimental purposes when there is limited material available (Ramachandran et al. 2004; Madison et al. 2015). In Japanese medaka, Madison et al. (2015) found that CEWAF treated with dispersant was 100 times more effective at supplying toxic concentrations of PAHs than WAF. Therefore, this treatment will be used in this study solely for the purpose of increasing PAH exposure given limited quantities of the characterized test material available.

\subsection{Effects of oil exposure on phase I detoxification and xenobiotic metabolic stress}

Biomarker assessment is an efficient method to determine the biological mechanisms and effects of pollutants such as PAHs in aquatic species (Van der Oost et al. 2003). Detoxification and xenobiotic metabolism involve a variety of enzymes that are important to assess as biomarkers that indicate PAH toxicity. For example, the induction of phase I detoxification is 
activated by the aryl hydrocarbon receptor (AhR). PAHs reach the cellular membrane and bind to the AhR, a ligand-activated basic-helix-loop-helix-Per-Arnt-Sim transcription factor, which regulates gene expression of enzymes that generate water-soluble products such as the oxygenase cytochrome P450 1A (CYP1A; Nebert et al. 2004). After a ligand binds to AhR, heat shock protein 90 (HSP90) is released and allows the AhR ligand complex to cross the nuclear membrane and dimerize with the aryl hydrocarbon receptor nuclear translocator (ARNT; Whyte et al. 2000). The AhR ligand/Arnt heterodimer then binds to dioxin responsive elements (DREs) on DNA, causing translation to RNA and transcription to protein products, such as CYP1A (Goksøyr and Husøy 1998; Ma 2001). The CYP1A family catalyzes oxidative reactions such as hydroxylation and sulfoxidation, leading to the reduction of xenobiotics to reactive oxygen species (ROS; Di Giulio et al. 1995; Regoli and Giuliani 2014).

The assessment of CYP1A response to cellular stress has been widely used in toxicology studies across species and contaminants. Exposure to planar aromatic hydrocarbons, including polychlorinated biphenyls, dioxins, and PAHs demonstrated by a statistically significant induction of cypla transcripts is indicative of an increased risk of toxicity (Whyte et al. 2000; Oris and Roberts 2007). In a study using juvenile and larval rainbow trout, exposure to a model cypla inducer $\beta$-naphthoflavone indicated that phenanthrene metabolism and toxicity increased, which supported the use of CYP1A activity as an indicator of PAH toxicity (Hawkins et al. 2002). Furthermore, CEWAF treatments have caused higher inductions of cypla transcripts than WAF treatments in rainbow trout (Oncorhynchus mykiss), due to increased PAH exposure (Ramachandran 2004). Likewise Madison et al. (2015) found that cypla mRNA levels were 15 times higher in WAF and 20 times higher in CEWAF exposed Japanese medaka compared to controls. A recent study by Alderman et al. (2017) found that CYP1A was upregulated in cardiac 
tissues of sockeye salmon. These studies indicate sublethal responses in gene expression during WAF and CEWAF exposures.

While CYP1A is commonly used as a toxicological indicator, it may not directly indicate the embryotoxicity of all oil PAHs. Incardona et al. (2005) suggested that since CYP1A is primarily induced by the least toxic $\mathrm{PAH}$, chrysene, it plays a protective role and may be less indicative of the toxicity of oil PAHs. For this reason it is valuable to assess other genes of interest to develop biomarkers across fish species. Furthermore, CYP1A may not necessarily correlate to downstream effects, even though it indicates hypoxia stress in fish (Incardona et al. 2005). Other genes involved in phase I metabolic stress may be used as biomarkers. In one study, $a h r$ and arnt 2 mRNA levels increased with dilbit exposure, forming a parallel bimodal trend, but this response was insufficient in confirming exposure-response patterns (Madison et al. 2015). Studies on the effects of the AhR agonist $\beta$-naphthoflavone and CYP1A inhibitor $\alpha$ naphthoflavone in zebrafish found that when CYP1A activity increased, AhR agonists were able to activate AhR for a longer time (Timme-Laragy et al. 2007). This may correlate with an increase in $a h r$ mRNA levels in fish exposed to oil PAHs once CYP1A is activated. Ultimately, further investigation is required to determine a range of biomarkers that can confirm toxic responses to various PAH homologues, which may be useful to compare species response.

\subsection{Effects of oil exposure on cellular stress and phase II detoxification}

The tumour suppressing protein p53 may be used as a biomarker for exposure mutations caused by cell cycling in vertebrates (Williams and Hubberstey 2014). The p53 gene can activate or repress cells when DNA is damaged by ROS or hypoxia stress, and cause cell apoptosis (Graeber et al. 1996; Lesser et al. 2001). Madison et al. (2015) found that p53 mRNA levels were unaffected by CEWAF treatments, but increased at the two highest WAF treatments. Other 
genes indicating cellular stress, such as heat shock protein 70 (HSP70) and glucose-6-phosphate dehydrogenase (G6PDH) also had increased mRNA levels in AWB dilbit WAF treatments (Madison et al. 2015). The in vivo end products of carcinogenic and mutagenic compounds can cause reactions with nucleophilic areas in DNA, leading to DNA adduct formation and carcinogenic response (Beland and Poirier 1989). DNA adduct levels respond when exposed to oil PAHs in English sole (Parophrys vetulus) and haddock (Melanogrammus aeglefinus; French et al. 1996; Balk et al. 2011). Hepatic DNA adducts develop when xenobiotic metabolites covalently bind to DNA and can be used as a biomarker for genotoxicity and carcinogenesis (Farmer and Shuker 1999; Balk et al. 2011).

Contaminants have significant effects on aquatic animals through oxidative stress, because aquatic animals are highly susceptible to toxicity by environmental exposure to dissolved contaminants (Lackner 1998). When animals experience oxidative stress, the cellular production of ROS generates antioxidant responses that may be used as biomarkers of PAH exposure. The synthesis of mRNAs occurs when superoxide dismutase (SOD) converts superoxide $\left(\mathrm{O}_{2}^{-}\right)$to hydrogen peroxide $\left(\mathrm{H}_{2} \mathrm{O}_{2}\right)$, catalase (CAT) converts $\mathrm{H}_{2} \mathrm{O}_{2}$ to $\mathrm{H}_{2} \mathrm{O}$, and glutathione peroxidase (GPx) and glutathione reductase (GSR) reduces glutathione (GSH) (Valavanidis et al. 2006). Madison et al. (2015) found that exposure of Japanese medaka to WAF and CEWAF dilbit increased mRNA levels in $g s r$ and sod. This study determined that mRNA levels for genes related to phase II detoxification significantly increased in WAF treatments and subtly increased in CEWAF treatments, with some decreases in mRNA levels in the highest CEWAF concentrations (Madison et al. 2015). WAF treatments have indicated that PAH exposure causes ROS to stimulate phase II reactions by reducing the lipophilicity of xenobiotics, (Regoli and Giuliani 2014; Madison et al. 2015). However, research is required to characterize 
the responses of phase II biomarkers in Canadian fish species and to understand the mechanisms of dilbit toxicity.

\subsection{Yellow Perch (Perca flavescens) life history and ecology}

Yellow perch (Perca flavescens) are an important game fish found East of the Rocky Mountains throughout North America. They are found in the littoral zone in shallow, near-shore waters, and are active year-round. Some of these life history traits may make yellow perch susceptible to an oil spill and to PAH toxicity. Once a year yellow perch congregate and spawn in calm and shallow areas of lakes or streams in sand, gravel, or dense vegetation (Krieger et al. 1983; Craig 1987). Hatching success and recruitment are highly dependent on available habitat, which may be detrimental to yellow perch populations in the event of a dilbit spill and clean-up procedure (Mangan 2004). Furthermore, their preference for lakes, ponds and slow streams may be deleterious to yellow perch should oil disperse slowly and prolong their exposure. Yellow perch eggs hatch from 10 to 20 days post-fertilization, depending on temperature, and the yolk sac is absorbed in the next five days (Lawler 1954; Trautman 1957; Whiteside et al. 1985). On average, yellow perch eggs are spawned in a jelly-like mass of 23,000 eggs that adhere to each other and to the substrate (Scott and Crossman 1973).

Yellow perch play a significant role in community ecology, as they are the prey of largemouth bass (Micropterus salmoides), walleye (Sander vitreus), and northern pike (Esox lucius). These species consume a large proportion of available juvenile yellow perch, and walleye are the main cause of their mortality at age one and two (Nielsen 1980). Through indirect effects, yellow perch abundance controls the intensity of predation on other forage fish, and reduces walleye cannibalism (Forney 1974). Yellow perch can even inhabit brackish and saline waters, which enables them to stay active throughout the winter (Scott and Crossman 
1973; Brown et al. 2009). For this reason, yellow perch may function as a transitional model for studies on other saline tolerant species that could be at risk in the event of a marine dilbit spill.

Environmental contaminants affect cellular cycling and phase I and II detoxification in yellow perch. Exposure to copper, a ROS catalyst, caused increased mRNA levels of sod-1 in wild yellow perch (Prousek 2007; Pierron et al. 2009). Studies of oxidative stress in yellow perch have shown increased activity of various enzymes including GSR, CAT, and GST; however, the activities varied across different contamination levels, suggesting that biomarker responses vary among different tissues (Dautremepuits et al. 2009). Yellow perch from polluted sites have also shown increased lipid peroxidation, indicating ROS activities and oxidative stress (Marcogliese et al. 2005). These studies show evidence of oxidative stress with contaminant exposure through the analysis of biomarkers in yellow perch.

\subsection{Research Objectives}

The objectives of this study were to compare the toxicity of both AWB and CLB dilbit on progeny from wild-sourced yellow perch. This study aims to assess changes in gene expression to determine potential biomarkers of dilbit toxicity. It is hypothesized that CLB will have a higher toxicity to yellow perch than AWB since CLB has a higher concentration of TPAHs than AWB. It is predicted that CLB treatments will have lower EC50s, increased malformations, and greater relative changes in genes involved in oxidative stress compared to AWB treatments. 


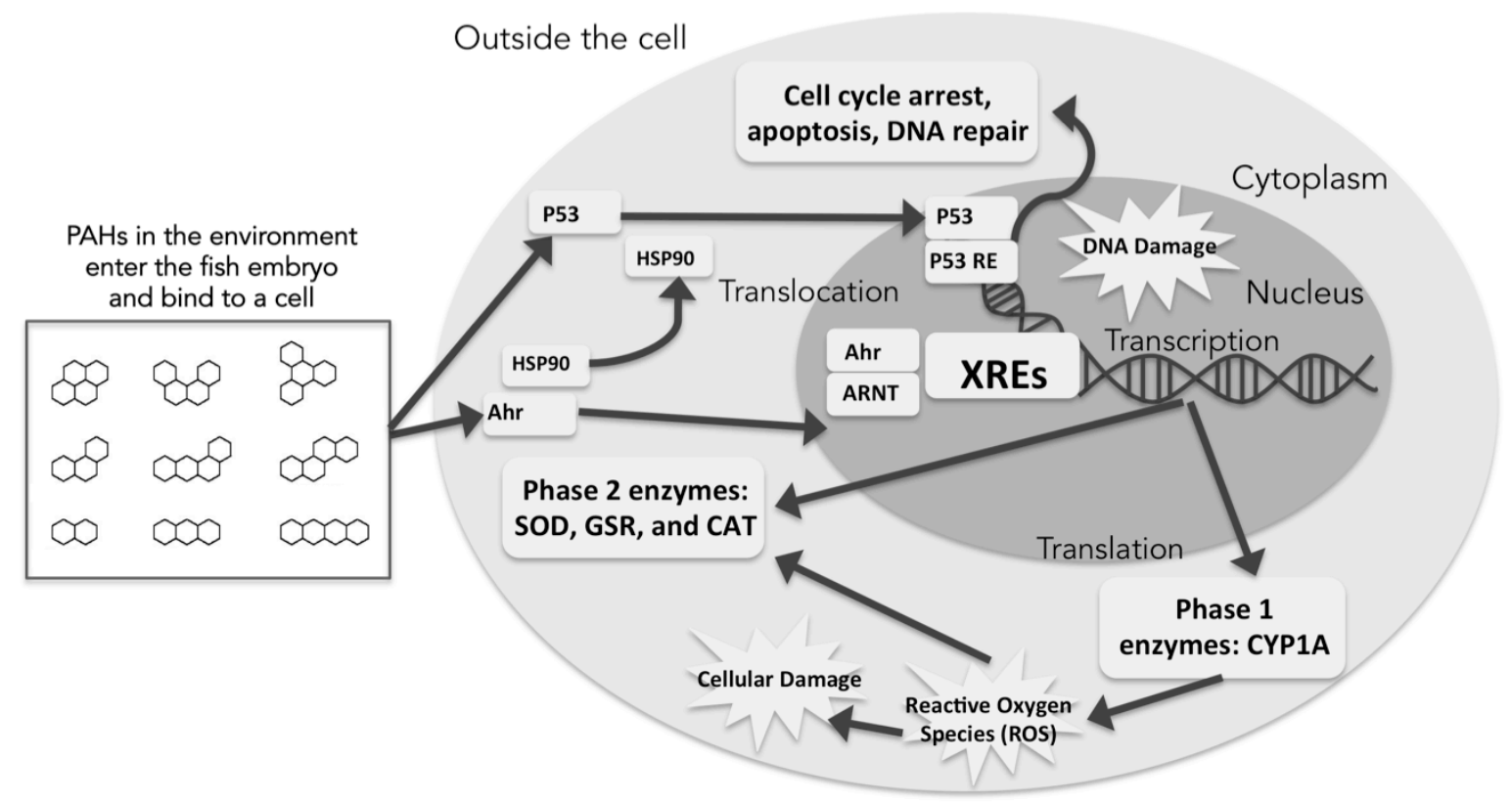

Figure 1. Mechanisms of PAH toxicity that will be assessed in this study. The embryo is exposed and bioavailable PAHs enter the fish through membranes. PAHs bind to the AhR, which releases HSP90. AhR translocates into the nucleus where it binds with ARNT. When this dimer binds to xenobiotic response elements (XREs) it causes the transcription of phase I detoxification enzymes (CYP1A) and phase II oxidation enzymes (GSR and CAT). CYP1A oxygenation of PAH produces reactive oxygen species (ROS) through redox reactions. ROS reactions also induce phase II oxidative stress enzymes by lowering the lipophilicity of PAHs. CYP1A oxygenation of PAH may also generate metabolites that cause DNA damage. However, phase II enzymes metabolize and limit ROS overproduction, DNA damage, and cellular damage. PAHs also bind to P53, causing a conformational change that turns P53 into a transcription activator. P53 is translocated into the nucleus and binds to P53 RE, which causes expression of several genes involved in cell cycle arrest, apoptosis, and DNA repair; binding of P53 also protects from accumulation of ROS and thus DNA damage (adapted from Regoli and Giuliani 2014). 


\section{METHODS AND MATERIALS}

This study simultaneously compared the toxicity of CLB and AWB dilbits to yellow perch, a critical mid-trophic level species in a number of continental watersheds. Embryos were exposed to AWB and CLB dilbits in WAF and CEWAF treatments using nominal concentrations of 0.32 to $32 \%(\mathrm{v} / \mathrm{v})$ and 0.0001 to $1 \%(\mathrm{v} / \mathrm{v})$, respectively. The comparative toxicity of AWB and CLB was assessed using mortality, malformations, and biomarkers indicative of xenobiotic metabolism (ahr), phase I detoxification (cypla), and phase II detoxification and cellular stress (gsr, cat, sodl, p53).

Animals. Wild sourced yellow perch embryos were obtained at one day post fertilization (dpf) from Kinmount Fish Farm, Kinmount, Kawartha Lakes, ON, Canada and transported at a constant temperature $\left(15 \pm 1^{\circ} \mathrm{C}\right)$ to Queen's University, Kingston, ON, Canada. The exposure commenced upon arrival of the embryos on May $6^{\text {th }}, 2016$. The embryos were kept in dechlorinated water from City of Kingston's municipal freshwater supply originating from Lake Ontario, $\mathrm{ON}$, Canada, at $15 \pm 1{ }^{\circ} \mathrm{C}, \mathrm{pH} 7.7 \pm 0.2$, and $7.4 \pm 0.2 \mathrm{mg} / \mathrm{L} \mathrm{O}$. All fish were held in accordance with approved protocols of Queen's University's Animal Care Committee and followed the Guidelines of the Canadian Council on Animal Care (Langlois-2015-1584).

Dilbit Preparation. AWB and CLB dilbits were chosen for this study because they are the highest volume products transported by pipeline in Canada and they have been chemically characterized previously (GOC 2013). Un-weathered AWB and CLB winter blend dilbit (from 2013 stocks; see King et al. 2014 for storage conditions) and Corexit ${ }^{\circledR}$ EC9500A oil dispersant (ECOLAB/NALCO, Illinois, USA) were kindly supplied by Mr. Thomas King, Fisheries and Oceans Canada (Dartmouth, NS). WAF and CEWAF treatments were made in $250 \mathrm{~mL}$ jars following methods of Madison et al. (2015). Both WAF and CEWAF for AWB and CLB were 
prepared by adding a 1:9 ratio of dilbit to water, and slowly stirring the solution for $18 \mathrm{~h}$, plus $1 \mathrm{~h}$ settling to allow soluble compounds in the oils to equilibrate with the water fraction and liquid phase oil droplets to float to the surface. Dispersant was added to CEWAF at a ratio of 1:20 parts oil, which was stirred for another hour and settled $(1 \mathrm{~h})$ prior to extraction of the soluble fraction. Stock solutions of all WAF and CEWAF for AWB and CLB were transferred to fresh vials using a sterile $60 \mathrm{~mL}$ syringe and blunt-tip $23 \mathrm{G}$ needle to prevent transfer of any visible surface oil in the soluble fraction. The dispersant control was prepared with non-toxic mineral oil (Nujol; Sigma-Aldrich, St. Louis, MO, USA) instead of dilbit to assess whether Corexit ${ }^{\circledR}$ EC9500A was causing toxicity to the embryos. The nominal concentrations for WAF and CEWAF were prepared daily and diluted in clean jars for static daily-renewal. Embryos were handled with gloves because the embryo strands were gelatinous, and carefully transferred in water to new jars. Glass jars used for exposure were cleaned each day with methanol to remove any oil, rinsed with dechlorinated water, and dried for the subsequent day.

Experimental design and sampling. Toxicity was tested according to the methods of Madison et al. (2015). Each treatment consisted of duplicate $250 \mathrm{~mL}$ jars of 60 embryos per treatment ( $\mathrm{n}=120$ per treatment) exposed $<24 \mathrm{hpf}$ to hatch. Jars were gently agitated on a New Brunswick Scientific Innova 2000 platform shaker (Eppendorf, Germany) at $60 \mathrm{rpm}$ to maintain water movement and to facilitate oxygen exchange at the surface of open-topped exposure jars. The treatments included three controls - a water control, a dispersant control (1\% v/v of Nujol mineral oil dispersed with Corexit ${ }^{\circledR}$ EC9500A) and a Nujol mineral oil control $(32 \% \mathrm{v} / \mathrm{v})$. There were five dilutions of WAF $(0.32,1,3.2,10,32 \% \mathrm{v} / \mathrm{v})$ and CEWAF $(0.0001,0.0010 .01,0.1,1 \%$ $\mathrm{v} / \mathrm{v}$ ) made from AWB and CLB stock dilbits in wide logarithmic ranges to determine sensitivity. Hatched eleuthero-embryos were sampled at the same time each day within the 7-16 dpf period. 
Embryos were immediately placed in buffered $\sim 100 \mu \mathrm{L}$ tricaine methanesulfonate (MS-222; $1 \mathrm{~g} / \mathrm{L})$ on glass slides to reduce embryo movement under the microscope. Embryos were photographed and scored for five malformations - pericardial edema (PE), tube heart (TH), yolk sac edema (YSE), craniofacial malformation (CF), and spinal malformation (S). Malformations were assessed each day during sampling as well as in a post-experimental double-blind analysis. Malformations were assessed using a Leica DMBL microscope (Leica, Germany).

Water Analysis. Daily water samples were taken from all treatments to determine total petroleum hydrocarbons measured by spectrofluorometry (TPH-F) and to assess daily variation in the dilution series for WAF and CEWAF exposures according to the method validated by Madison et al. (2015) and Adams et al. (2014a). Standard curves for AWB and CLB parent oils were determined from the fluorescence peak excitation-emission area. TPH-F content was compared to nominal loadings $(\% \mathrm{v} / \mathrm{v})$ of each dilbit WAF and CEWAF and to TPAH to estimate the TPAH concentration $(\mu \mathrm{g} / \mathrm{L})$ in WAF and CEWAF treatments of AWB and CLB. The three highest WAF and CEWAF exposures were analyzed for PAH concentrations by gas chromatography-mass spectrometry (GC-MS); the remaining treatments were not analyzed because the limits of detection were not low enough. Two-500 $\mathrm{mL}$ samples were independently prepared by the same method for AWB and CLB WAF $(3.2,10,32 \% \mathrm{v} / \mathrm{v})$ and CEWAF $(0.01$, $0.1,1 \% \mathrm{v} / \mathrm{v}$ ) dilutions and assessed by AGAT protocols for TPAH concentrations (AGAT Laboratories, Montreal, Quebec, Canada). Daily water samples were compared to determine the relationship between TPAH content with nominal dilutions and the TPH-F concentration.

qPCR Analysis. Total RNA was extracted using TrIzol ${ }^{\circledR}$ Reagent (Ambion ${ }^{\mathrm{TM}}$ RNA by Life Technologies, Carlsbad, CA, USA). Fish were pooled before RNA extraction in groups of five to obtain enough mRNA for qPCR, with malformed and normal fish pooled separately. The 
samples were kept on ice throughout the RNA isolation protocol. Isolated RNA was resuspended in $20 \mu \mathrm{L}$ RNase free water and concentrations were measured using a NanoDrop2000 spectrophotometer (Thermo-Fisher, Ottawa, ON, Canada), which was used as a template to synthesize complementary DNA (cDNA) with a QuantiTect Reverse Transcription Kit (QIAGEN, Ottawa, ON, CA). Primers and nuclease-free water were added to $1 \mu \mathrm{g}$ RNA according the manufacturer's protocol, incubated for $2 \mathrm{~min}$ at $42{ }^{\circ} \mathrm{C}$, and placed on ice. Master mix containing RNase free water, gDNA Wipeout Buffer (Quantiscript), reverse transcriptase, Quantiscript RT buffer, RT primer mix, and nuclease free water was added according to the manufacturer's protocol. Samples were placed in the thermocycler for 15 min at $42{ }^{\circ} \mathrm{C}$ and inactivated at $95^{\circ} \mathrm{C}$ for $3 \mathrm{~min}$. A total 168 of $0.5 \mu \mathrm{g}$ of cDNA was made for qPCR. The cDNA products were diluted 80-fold prior to PCR amplification based on optimization runs for the genes of interest (cypla, ahr, gsr, cat, sod,p53). Samples were run in triplicate, including samples without reverse-transcriptase, no-template controls, and positive water controls.

Data Analysis. Median effective concentrations (EC50) were calculated using Sigmoidal, 4PL, $\mathrm{X}$ is $\log$ (concentration) analysis, which is a four parameter logistic regression (GraphPad Prism 6, GraphPad Software Inc., San Diego, CA, USA). Gene expression was shown by mean \pm SEM that was normalized to the mean of the two housekeeping genes, efla and rpl8. The x-axis describes the logarithmic mean concentration of total polycyclic aromatic hydrocarbons (TPAH) present in each treatment. WAF treatments were compared to the water control, and CEWAF treatments were compared to the dispersant control using one-way analysis of variance (ANOVA) and Holm-Sidak post hoc analysis $(p<0.05)$. 
Table 1. Genes of interest and their associated biological function, accession number, primer efficiency (\%), primer sequences, and amplicon length (bp).

\begin{tabular}{|c|c|c|c|c|c|c|}
\hline $\begin{array}{l}\text { Associate } \\
\text { Biological } \\
\text { function }\end{array}$ & $\begin{array}{l}\text { Gene of } \\
\text { Interest }\end{array}$ & $\begin{array}{l}\text { Primer } \\
\text { efficiency } \\
(\%)\end{array}$ & Forward Primer (5'-3') & Reverse Primer (5'-3') & $\begin{array}{l}\text { Amplicon } \\
\text { Length } \\
\text { (bp) }\end{array}$ & Reference \\
\hline $\begin{array}{l}\text { Housekeeping } \\
\text { gene }\end{array}$ & $e f 1 a^{*}$ & 91.7 & CGAGAAGGAAGCCCAAGAGA & GCCTCAAACTCACCAACACC & 249 & $\begin{array}{l}\text { Martin et al. } \\
2016\end{array}$ \\
\hline $\begin{array}{l}\text { Housekeeping } \\
\text { gene }\end{array}$ & $\operatorname{rpl} 8^{*}$ & 91.9 & GAGCATCCCTTCGGTGGT & GGCGTCCCTCCTGATTGT & 66 & $\begin{array}{l}\text { Martin et al. } \\
2016\end{array}$ \\
\hline $\begin{array}{l}\text { Xenobiotic } \\
\text { metabolism }\end{array}$ & $a h r$ & 91.9 & CCAGACCAAACACAAGCTGGAC & TCGGCGGCGTGGATGAACTG & 126 & This study \\
\hline Phase II & cat & 90.6 & CCTGTGGGCAAAATGGT & TGACGATGTGTGTCTGGGTAG & 161 & $\begin{array}{l}\text { Martin et al. } \\
2016\end{array}$ \\
\hline Phase I & cypla & 92.1 & СТАCTTCACCCCAAAGACACC & САТСАССТТСТСТСССТСТАСС & 154 & $\begin{array}{l}\text { Martin et al. } \\
2016\end{array}$ \\
\hline Phase II & $g s r$ & 93.2 & CTGGTGTGGATGTGTGGAAG & CGAACTTCTCCTCGTCGTTC & 117 & $\begin{array}{l}\text { Martin et al. } \\
2016\end{array}$ \\
\hline Phase II & $\operatorname{sod} 1$ & 93.4 & GCATGTAGGAGACTTGGGCAAT & CCGTGATTTCTATCTTGGCAACA & 64 & $\begin{array}{l}\text { Martin et al. } \\
2016\end{array}$ \\
\hline $\begin{array}{l}\text { Cell cycling/ } \\
\text { mutation } \\
\text { response }\end{array}$ & p53 & 91.7 & GCAGACCCATCCTCACCATC & CCAGGACAGGCACATACACG & 93 & This study \\
\hline $\begin{array}{l}\text { Elongation } \\
\text { receptor }(a) \\
(g s r) \text {; supe1 }\end{array}$ & ctor 1 . & ha* (ef & ochrome P4501A & $\begin{array}{l}\text { * (rpl8); aryl hydro } \\
\text { la); glutathione red } \\
\text { otein p53 (p53). }\end{array}$ & $\begin{array}{l}\text { bon } \\
\text { tase }\end{array}$ & \\
\hline
\end{tabular}




\section{RESULTS}

\subsection{Survivorship}

Hatching success was more than $85 \%$ for all treatments except for the highest AWB WAF and CLB WAF treatments (Table 2). In the highest AWB WAF, only $2.8 \%$ of fish successfully hatched at $5.3 \mu \mathrm{g} / \mathrm{L}$ TPAH, while in CLB WAF, $70 \%$ successfully hatched at 11 $\mu \mathrm{g} / \mathrm{L}$ TPAH. Hatching was $100 \%$ in two treatments: the second highest CLB WAF with $3.3 \%$ $\mu \mathrm{g} / \mathrm{L}$ TPAH, and the highest AWB CEWAF with $1.4 \mu \mathrm{g} / \mathrm{L}$ TPAH. Hatching success in the water control and dispersant control was $96 \%$ and $95 \%$, respectively. The $\%$ hatch of embryos was little different from the controls in CEWAF treatments, but lower than controls in the highest WAF treatments, where only 3 fish survived in the highest AWB WAF.

\subsection{Malformations}

Embryo development was affected by dilbit exposure, which was evident in malformations at the highest AWB and CLB concentrations of WAF and CEWAF (Table 2). The highest concentrations of WAF caused the most malformations, with $100 \%$ and $98 \%$ affected, respectively. Yellow perch embryos exposed to the highest treatment of AWB CEWAF were 43 $\%$ affected, and $63 \%$ affected after exposure to CLB CEWAF. Pericardial edema was consistently the most common malformation in affected fish, which was present in $90 \%$ of water control, $75 \%$ of dispersant control, $97 \%$ of AWB and CLB WAF, $89 \%$ of AWB CEWAF, and $92 \%$ of CLB CEWAF exposed embryos (Table 3). Tube heart was the next most prevalent malformation in affected fish, present in $30 \%$ of water control, $25 \%$ of dispersant control, $47 \%$ of AWB WAF, $83 \%$ CLB WAF, $27 \%$ AWB CEWAF, and $25 \%$ of CLB CEWAF exposed embryos. The estimated EC50 for the prevalence of malformations was 2.8 and $6.4 \mu \mathrm{g} / \mathrm{L} \mathrm{TPAH}$ 
for AWB and CLB WAF, respectively. In CEWAF treatments, the estimated EC50s were 18 $\mu \mathrm{g} / \mathrm{L}$ TPAH for CLB CEWAF, and $>1.4 \mu \mathrm{g} / \mathrm{L}$ TPAH for AWB CEWAF.

\subsection{AWB and CLB oxidative stress}

After the AWB and CLB dilbit exposure, biomarkers of phase I and II detoxification and oxidative stress were assessed (Table 4). Sigmoidal exposure responses were observed for cypla in fish exposed to WAF (CLB R ${ }^{2}=0.93$; AWB $^{2}=0.88 ; p<0.0001 ; n=6-8$; Figure 3 a) and CEWAF (CLB R ${ }^{2}=0.99 ;$ AWB R ${ }^{2}=0.65 ; \mathrm{p}<0.0001 ; \mathrm{n}=6-8$; Figure $3 \mathrm{~b}$ ). AWB and CLB exposure induced cypla mRNA levels by up to 18 -fold in WAF and 50-fold in CEWAF treatments, compared to controls. No trends were seen for $c a t$, gsr, or $a h r$ in WAF treatments (Figure $3 \mathrm{c}, \mathrm{e}, \mathrm{g}$ ). However, fish exposed to AWB CEWAF displayed exposure-response trends with a [Agonist] vs. response- Variable slope (four parameters) regression, and exhibited significant 5, 35, and 3-fold increases in cat, gsr, and $a h r$, respectively $\left(\mathrm{R}^{2}=0.80 ; \mathrm{R}^{2}=0.66\right.$; $\mathrm{R}^{2}=0.24 ; \mathrm{p}<0.0001$; Figure $\left.3 \mathrm{~d}, \mathrm{f}, \mathrm{h}\right)$. No regression trends were evident for sod or $p 53$, although CLB WAF at $0.25 \mu \mathrm{g} / \mathrm{L}$ TPAH was significantly different for sod and $p 53$, and AWB WAF at $0.55 \mu \mathrm{g} / \mathrm{L}$ TPAH was significantly different for $p 53(\mathrm{p}<0.0001$; Figure $4 \mathrm{a}, \mathrm{b})$. 
Table 2. \% Hatch Success and \% Affected for yellow perch embryos after 16 days exposure to water control and dispersant control treatments, and to increasing concentrations of AWB WAF (0.080-5.3 $\mu \mathrm{g} / \mathrm{L}$ TPAH) and CEWAF (0.21-1.4 $\mu \mathrm{g} / \mathrm{L}$ TPAH); and of CLB WAF $(0.020-11 \mu \mathrm{g} / \mathrm{L}$ TPAH) and CEWAF (1.3-20 $\mu \mathrm{g} / \mathrm{L}$ TPAH) dilbits.

\begin{tabular}{|c|c|c|c|c|}
\hline Exposure & $\begin{array}{c}\text { Nominal } \\
\text { Loading (\% } \\
\text { v/v) }\end{array}$ & TPAH $(\mu \mathrm{g} / \mathrm{L})$ & $\begin{array}{l}\text { \% Hatch } \\
\text { Success }\end{array}$ & $\begin{array}{c}\text { \% Affected } \\
\text { (Minimum one } \\
\text { malformation) }\end{array}$ \\
\hline Water Control & 0.1 & 1 & 96 & 4.3 \\
\hline Dispersant Control & 0.1 & 1 & 95 & 6.1 \\
\hline \multirow[t]{5}{*}{ AWB WAF } & 0.32 & 0.080 & 95 & 2.2 \\
\hline & 1 & 0.19 & 99 & 2.2 \\
\hline & 3.2 & 0.55 & 93 & 5.9 \\
\hline & 10 & 1.7 & 95 & 11 \\
\hline & 32 & 5.3 & 2.8 & 100 \\
\hline \multirow[t]{5}{*}{ CLB WAF } & 0.32 & 0.020 & 90 & 5.4 \\
\hline & 1 & 0.25 & 98 & 2.6 \\
\hline & 3.2 & 0.99 & 98 & 5.9 \\
\hline & 10 & 3.3 & 100 & 4.0 \\
\hline & 32 & 11 & 70 & 98 \\
\hline \multirow[t]{5}{*}{ AWB CEWAF } & 0.0001 & 0.21 & 93 & 4.4 \\
\hline & 0.001 & 0.21 & 87 & 4.2 \\
\hline & 0.01 & 0.22 & 96 & 6.7 \\
\hline & 0.1 & 0.33 & 85 & 6.9 \\
\hline & 1 & 1.4 & 100 & 43 \\
\hline \multirow[t]{5}{*}{ CLB CEWAF } & 0.0001 & 1.3 & 92 & 3.5 \\
\hline & 0.001 & 1.4 & 90 & 7.7 \\
\hline & 0.01 & 1.5 & 89 & 4.5 \\
\hline & 0.1 & 3.2 & 84 & 7.0 \\
\hline & 1 & 20 & 90 & 63 \\
\hline
\end{tabular}


Table 3. A frequency index (\%) of individual developmental malformations of total malformed yellow perch at hatch following exposure to Cold Lake Blend (CLB) and Access Western Blend (AWB) diluted bitumen (dilbit) water accommodated fractions (WAF) and chemically-enhanced WAF (CEWAF) treatment for up to 16 days.

\begin{tabular}{|c|c|c|c|c|c|c|}
\hline \multirow{2}{*}{$\begin{array}{l}\text { Water Control + } \\
\text { Dispersant } \\
\text { Control } \\
\text { Malformation }(\%) \text { : }\end{array}$} & \multicolumn{5}{|c|}{ Treatment: } & \\
\hline & $\begin{array}{l}\text { Water } \\
\text { control }\end{array}$ & \multicolumn{4}{|c|}{$\begin{array}{c}\text { Dispersant Control (1\% v/v of Nujol mineral oil } \\
\text { dispersed with Corexit }{ }^{\circledR} \text { EC9500A) }\end{array}$} & \\
\hline Craniofacial & 20 & \multicolumn{4}{|c|}{-} & \\
\hline Spinal/Tail & 20 & \multicolumn{4}{|c|}{13} & \\
\hline Yolk sac edema & 60 & \multicolumn{4}{|c|}{25} & \\
\hline $\begin{array}{l}\text { Pericardial } \\
\text { edema }\end{array}$ & 90 & \multicolumn{4}{|c|}{75} & \\
\hline Tube heart & 30 & \multicolumn{4}{|c|}{25} & \\
\hline Total malformed: & 10 & \multicolumn{4}{|c|}{8} & \\
\hline Total $(n)$ & 261 & \multicolumn{4}{|c|}{112} & \\
\hline AWB WAF & \multicolumn{5}{|c|}{ Nominal Concentration $(\% v / v)$ : } & \multirow{2}{*}{$\begin{array}{l}\text { Proportion } \\
\text { of Total }(\%)\end{array}$} \\
\hline Malformation $(\%)$ : & 0.32 & 1 & 3.2 & 10 & 32 & \\
\hline Craniofacial & - & - & 29 & 25 & 100 & 30 \\
\hline Spinal/Tail & - & - & 57 & 19 & 100 & 33 \\
\hline Yolk sac edema & - & 50 & 29 & 25 & 100 & 33 \\
\hline $\begin{array}{l}\text { Pericardial } \\
\text { edema }\end{array}$ & 100 & 50 & 100 & 100 & 100 & 97 \\
\hline Tube heart & 50 & - & 43 & 44 & 100 & 47 \\
\hline Total malformed: & 2 & 2 & 7 & 16 & 3 & 30 \\
\hline Total (n) & 90 & 91 & 118 & 143 & 3 & 445 \\
\hline
\end{tabular}

\section{CLB WAF}

Malformation (\%):

\begin{tabular}{|c|c|c|c|c|c|c|}
\hline Craniofacial & 40 & 67 & 43 & 40 & 77 & 71 \\
\hline Spinal/Tail & - & 33 & 29 & 40 & 54 & 48 \\
\hline Yolk sac edema & 20 & 33 & 29 & 40 & 91 & 79 \\
\hline $\begin{array}{l}\text { Pericardial } \\
\text { edema }\end{array}$ & 80 & 67 & 100 & 100 & 99 & 97 \\
\hline Tube heart & - & 33 & 43 & 60 & 95 & 83 \\
\hline Total malformed: & 5 & 3 & 7 & 5 & 79 & 99 \\
\hline Total $(n)$ & 92 & 115 & 118 & 124 & 81 & 530 \\
\hline
\end{tabular}




\begin{tabular}{lcccccc}
\hline AWB CEWAF & \multicolumn{6}{c}{ Nominal Concentration $(\%$ v/v): } \\
\cline { 2 - 6 } Malformation (\%): & $\mathbf{0 . 0 0 0 1}$ & $\mathbf{0 . 0 0 1}$ & $\mathbf{0 . 0 1}$ & $\mathbf{0 . 1}$ & $\mathbf{1}$ & \\
\hline Craniofacial & 50 & 25 & 13 & 33 & 6 & 13 \\
Spinal/Tail & - & 25 & 25 & 33 & 4 & 10 \\
Yolk sac edema & 75 & 75 & 25 & 17 & 15 & 23 \\
Pericardial & 75 & 75 & 38 & 100 & 98 & 89 \\
edema & 50 & 50 & - & 67 & 23 & 27 \\
Tube heart & 4 & 4 & 8 & 6 & 48 & 70 \\
\hline Total malformed: & 90 & 96 & 120 & 87 & 112 & 505 \\
\hline \multicolumn{1}{c}{ Total $(n)$} & 90
\end{tabular}

\section{CLB CEWAF}

\begin{tabular}{|c|c|c|c|c|c|c|}
\hline Craniofacial & 50 & 25 & 20 & 17 & 4 & 9 \\
\hline Spinal/Tail & - & 25 & - & - & 1 & 3 \\
\hline Yolk sac edema & - & 63 & 20 & 17 & 8 & 16 \\
\hline $\begin{array}{l}\text { Pericardial } \\
\text { edema }\end{array}$ & 75 & 63 & 20 & 100 & 100 & 92 \\
\hline Tube heart & - & 38 & - & 67 & 23 & 25 \\
\hline Total malformed: & 4 & 8 & 5 & 6 & 71 & 94 \\
\hline Total $(n)$ & 116 & 104 & 111 & 86 & 113 & 530 \\
\hline
\end{tabular}



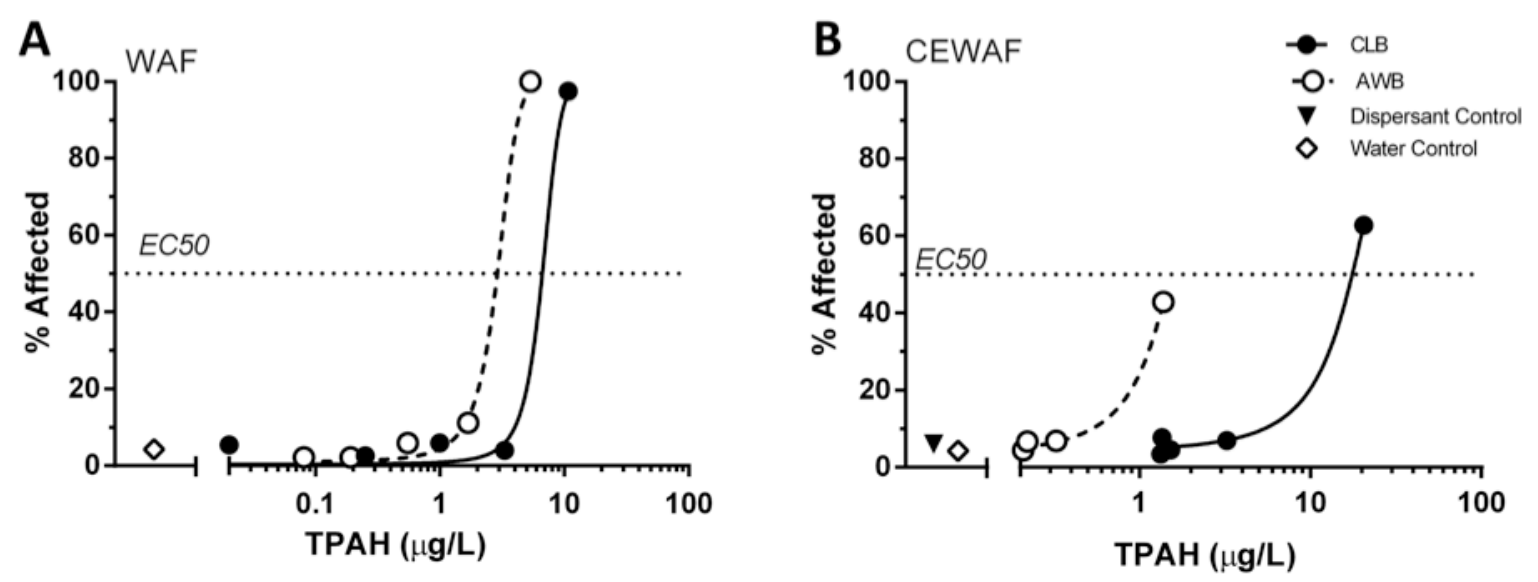

Figure 2. \% Affected embryos with at least one malformation and the TPAH $(\mu \mathrm{g} / \mathrm{L})$ measured by GC-MS. A) Sigmoidal, 4PL, $\mathrm{X}$ is $\log$ (concentration). $\mathrm{CLB} \mathrm{R}^{2}=0.99 ; \mathrm{AWB}^{2}=1.00 \mathrm{~B}$ ) Sigmoidal, 4PL, $\mathrm{X}$ is $\log$ (concentration). $\mathrm{CLB} \mathrm{R}^{2}=1.00$; $\mathrm{AWB}^{2}=1.00$. 

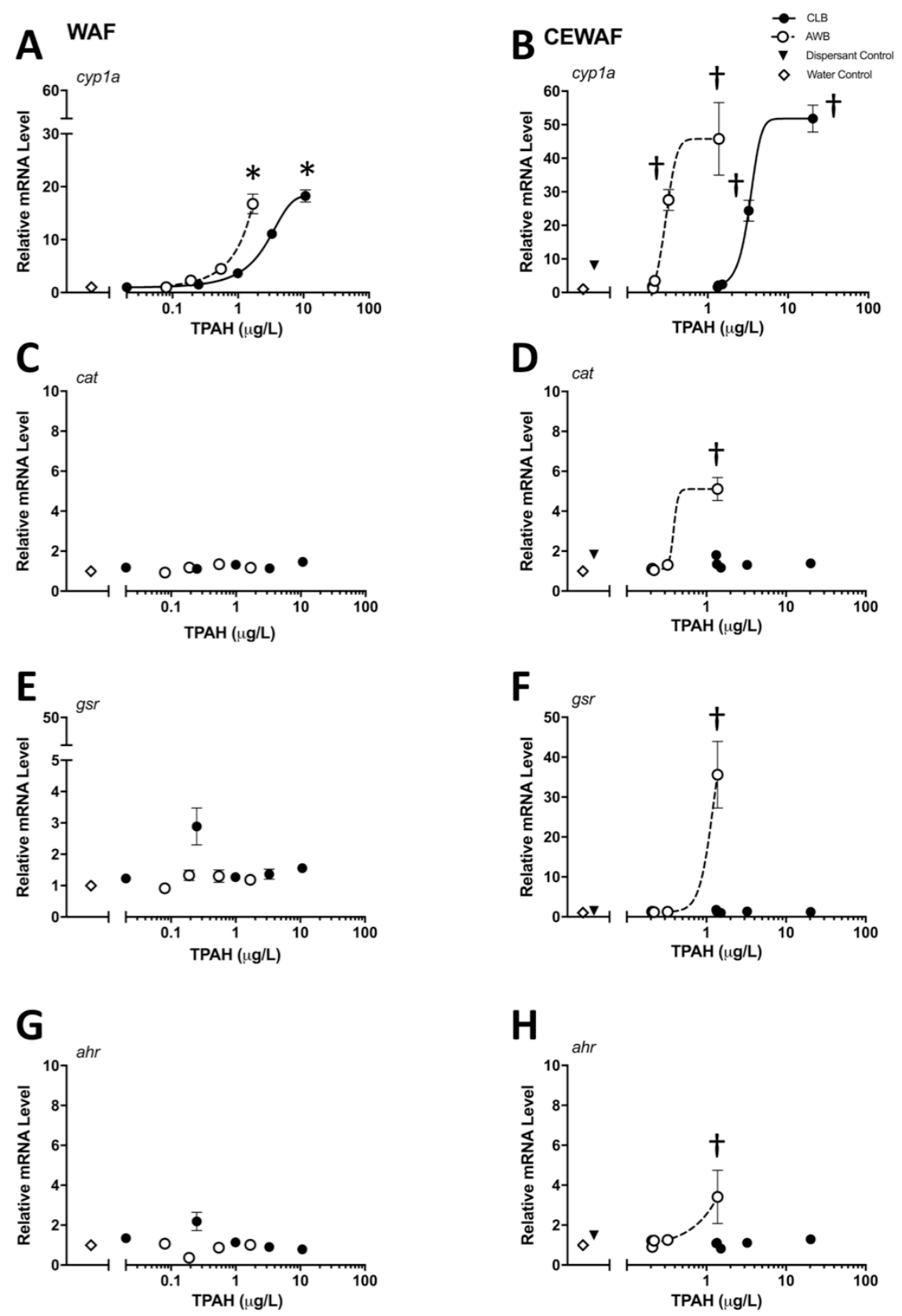

Figure 3. mRNA levels of cypla, cat, gsr, and $a h r$ normalized to the mean of the housekeeping genes (efla and $r p L 8)$ compared to the concentrations of TPAH ( $\mu \mathrm{g} / \mathrm{L})$. A) Sigmoidal, 4PL, X is $\log$ (concentration). CLB $\left.\mathrm{R}^{2}=0.93 ; \mathrm{AWB}^{2}=0.88 ; p<0.001 ; \mathrm{n}=6-8 . \mathrm{B}\right)$ Sigmoidal, 4PL, $\mathrm{X}$ is $\log$ (concentration). CLB R $\left.{ }^{2}=0.99 ; \mathrm{AWB} \mathrm{R}^{2}=0.65 ; p<0.0001 ; \mathrm{n}=6-8 . \mathrm{C}\right) \mathrm{n}=6-8 \mathrm{D}$ ) 
[Agonist] vs. response- Variable slope (four parameters). $\mathrm{AWB} \mathrm{R}^{2}=0.80 ; p<0.0001 ; \mathrm{n}=6-8$. E) $n=7-8 . F$ ) [Agonist $]$ vs. response- Variable slope (four parameters). AWB $R^{2}=0.66 ; p<$ 0.0001; $\mathrm{n}=6-8 . \mathrm{G}) \mathrm{n}=7-8 . \mathrm{H}$ ) [Agonist] vs. response- Variable slope (four parameters). AWB $\mathrm{R}^{2}=0.24 ; p<0.01 ; \mathrm{n}=7-8 .(*)$ means WAF is significantly different from water control; $(\dagger)$ means CEWAF is significantly different from dispersant control, where $p<0.05$.
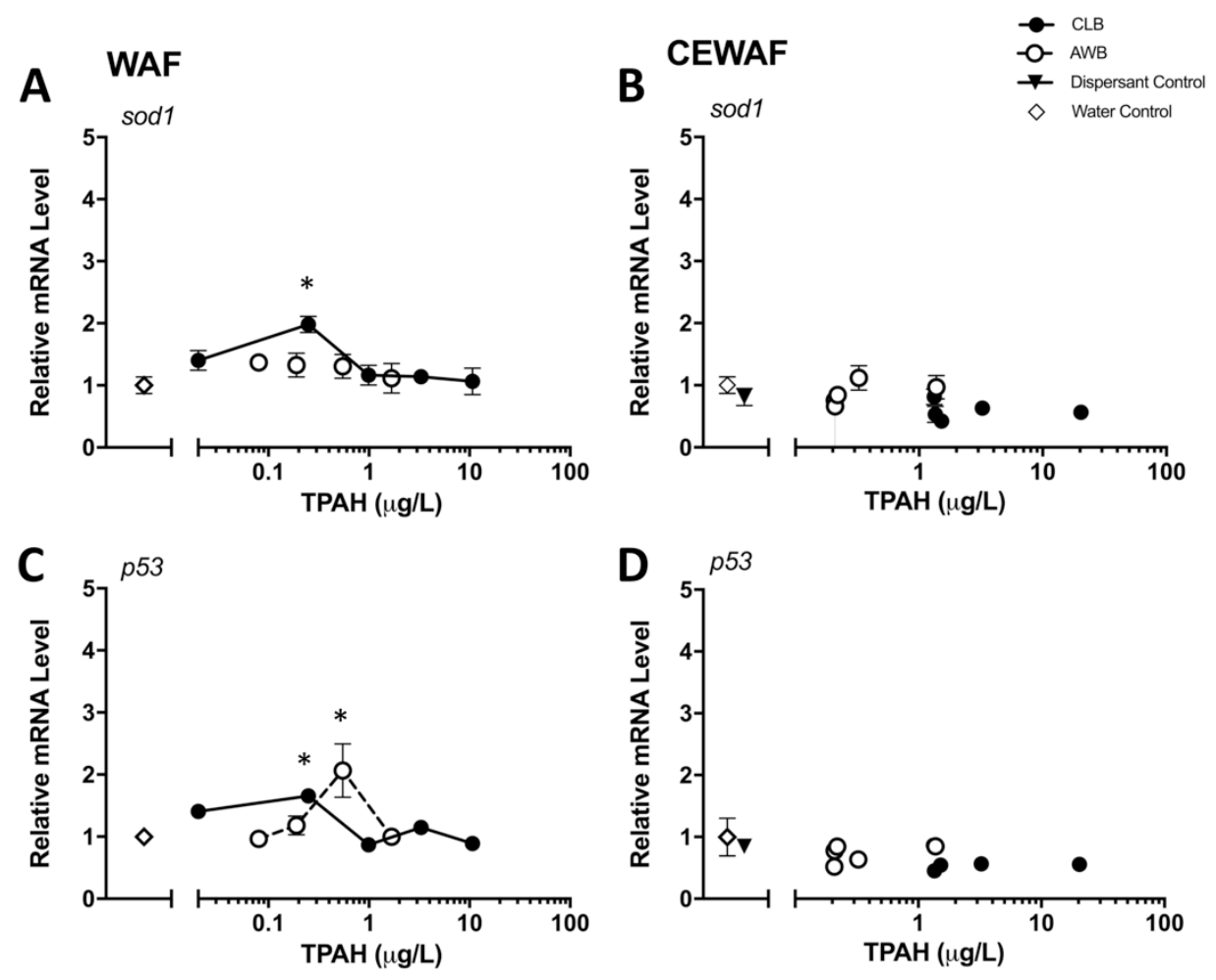

Figure 4. mRNA levels of sod and p53 normalized to the mean of the housekeeping genes (efla and $r p L 8)$ compared to the concentrations of TPAH $(\mu \mathrm{g} / \mathrm{L})$. A) No regression. $p<0.001 ; \mathrm{n}=7-8$ B) No regression. $\mathrm{n}=7-8$. C) No regression. AWB $p<0.0001$, CLB $p<0.05$; $\mathrm{n}=7-8$. D) No regression. $p<0.05 \mathrm{~N}=7-8$. $(*)$ means $\mathrm{WAF}$ is significantly different from water control; $(\dagger)$ means CEWAF is significantly different from dispersant control, where $p<0.05$. 
Table 4. A summary of the significant changes in gene expression of yellow perch embryos after 16 days exposure to WAF and CEWAF of AWB and CLB dilbit. Relative levels of mRNA were normalized to the mean of the housekeeping genes, efla and $r p l 8$, and relative to respective control treatments. Significant differences between WAF (AWB, CLB) and water control, and between CEWAF (AWB, CLB) and dispersant control are noted as indicated by 1-way ANOVA and Holm-Sidak's post hoc analysis $(p<0.05)$.

\begin{tabular}{llll}
\hline $\begin{array}{l}\text { Associate } \\
\text { Biological } \\
\text { function }\end{array}$ & $\begin{array}{l}\text { Gene of } \\
\text { Interest }\end{array}$ & $\begin{array}{l}\text { Significant Change } \\
\text { in gene expression } \\
\text { in CLB }\end{array}$ & $\begin{array}{l}\text { Significant Change } \\
\text { in gene expression } \\
\text { in AWB }\end{array}$ \\
\hline $\begin{array}{l}\text { Xenobiotic } \\
\text { metabolism }\end{array}$ & $a h r$ & & CEWAF \\
Phase II & $c a t$ & WAF; CEWAF & WAF; CEWAF \\
$\begin{array}{l}\text { Phase I } \\
\text { cypla }\end{array}$ & & CEWAF \\
$\begin{array}{l}\text { Phase II } \\
\text { Phase II }\end{array}$ & sod1 & WAF & \\
$\begin{array}{l}\text { Cell } \\
\text { cycling/mutation } \\
\text { response }\end{array}$ & p53 & WAF & \\
\end{tabular}


Table 5. Regressions of responses on dilbit exposure concentrations of $\%$ affected and gene expression data in mean relative mRNA levels to Access Western Blend (AWB) and Cold Lake Blend (CLB) WAF and CEWAF dilbits over a 16-day exposure to yellow perch embryos. The regressions include Sigmoidal, 4PL, $\mathrm{X}$ is $\log$ (concentration) where $y=$ Bottom $+\frac{\text { Top-bottom }}{1+10^{(\log E C 50-x)-\text { Hillslope }}}$ and [Agonist] vs. response- Variable slope (four parameters $)$ where $y=$ Bottom $+\left(X^{\text {Hillslope }}\right) * \frac{\text { Top-Bottom }}{\left(x^{\text {Hillslope }}+E C 0^{\text {Hillslope }}\right)}$.

\begin{tabular}{|c|c|c|c|c|}
\hline \multirow{2}{*}{$\begin{array}{l}\text { Figure/ } \\
\text { variable/ } \\
\text { treatments }\end{array}$} & \multirow[t]{2}{*}{ Regression type } & \multirow[t]{2}{*}{ Parameter } & \multicolumn{2}{|r|}{ Exposure } \\
\hline & & & AWB & CLB \\
\hline $2 / \%$ & Sigmoidal, & Upper & 1.00 & 1.00 \\
\hline \multirow{3}{*}{ Affected/WAF } & 4PL, $\mathrm{X}$ is $\log$ & Lower & 0 & 0 \\
\hline & (concentration) & $r^{2}$ & 1.00 & 0.99 \\
\hline & & EC50 & 2.83 & 6.42 \\
\hline $2 / \%$ & Sigmoidal, & Upper & 1.00 & 1.00 \\
\hline \multirow{3}{*}{ Affected/CEWAF } & 4PL, $\mathrm{X}$ is $\log$ & Lower & 0 & 0 \\
\hline & (concentration) & $r^{2}$ & 1.00 & 1.00 \\
\hline & & EC50 & & 17.5 \\
\hline \multirow{5}{*}{ 3b/cypla/WAF } & Sigmoidal, & $95 \%$ CI Top & $16.87-19.88$ & (very wide) \\
\hline & $4 \mathrm{PL}, \mathrm{X}$ is $\log$ & $95 \%$ CI Bottom & $-7.34-8.966$ & (very wide) \\
\hline & (concentration) & $r^{2}$ & 0.93 & 0.88 \\
\hline & & $p$-value & $<0.01$ & $<0.001$ \\
\hline & & HillSlope & 0.2599 & $\sim 0.2782$ \\
\hline $3 \mathrm{~b} /$ cyplal & Sigmoidal, & 95 \% CI Top & $35.67-55.87$ & $47.35-56.27$ \\
\hline \multirow[t]{4}{*}{ CEWAF } & 4PL, $\mathrm{X}$ is $\log$ & $95 \%$ CI Bottom & $-169.3-151.8$ & $-27.1-27.34$ \\
\hline & (concentration) & $r^{2}$ & 0.65 & 0.92 \\
\hline & & $p$-value & $<0.0001$ & $<0.0001$ \\
\hline & & HillSlope & 8.015 & 0.7393 \\
\hline $3 \mathrm{c} / c a t / \mathrm{WAF}$ & No regression & & & \\
\hline \multirow[t]{5}{*}{ 3d/cat/CEWAF } & [Agonist] vs. & 95 \% CI Top & $4.539-5.684$ & \\
\hline & response- & $95 \%$ CI Bottom & $0.1385-2.04$ & \\
\hline & Variable slope & & 0.82 & \\
\hline & (four & $p$-value & $<0.0001$ & \\
\hline & parameters). & HillSlope & $\sim 15.9$ & \\
\hline $3 \mathrm{e} / g s r / \mathrm{WAF}$ & No regression & & & \\
\hline
\end{tabular}




\begin{tabular}{|c|c|c|c|c|}
\hline $3 \mathrm{f} / g_{s r} / \mathrm{CEWAF}$ & $\begin{array}{l}\text { [Agonist] vs. } \\
\text { response- } \\
\text { Variable slope } \\
\text { (four } \\
\text { parameters). }\end{array}$ & $\begin{array}{l}95 \% \text { CI Top } \\
95 \% \text { CI Bottom } \\
r^{2} \\
p \text {-value } \\
\text { HillSlope }\end{array}$ & $\begin{array}{l}-58.01-60.41 \\
\text { (very wide) } \\
0.66 \\
<0.0001 \\
\sim 4.948\end{array}$ & \\
\hline $3 \mathrm{~g} / a h r / \mathrm{WAF}$ & No regression & & & \\
\hline 3h/ahr/CEWAF & $\begin{array}{l}\text { [Agonist] vs. } \\
\text { response- } \\
\text { Variable slope } \\
\text { (four } \\
\text { parameters). }\end{array}$ & $\begin{array}{l}95 \% \text { CI Top } \\
95 \% \text { CI Bottom } \\
r^{2} \\
p \text {-value } \\
\text { HillSlope }\end{array}$ & $\begin{array}{l}\text { (very wide) } \\
\text { (very wide) } \\
0.24 \\
<0.01 \\
\sim 1.331\end{array}$ & \\
\hline 4a/sod/WAF & No regression & $p$-value & & $<0.001$ \\
\hline 4b/sod/CEWAF & No regression & & & \\
\hline $4 \mathrm{c} / p 53 / \mathrm{WAF}$ & No regression & $p$-value & $<0.0001$ & $<0.05$ \\
\hline $4 \mathrm{~d} / p 53 / \mathrm{CEWAF}$ & No regression & & & \\
\hline
\end{tabular}




\section{DISCUSSION}

This study exposed two Canadian dilbits to developing yellow perch to compare hatching success, malformations, and relative changes in gene expression. This is the first experiment to simultaneously compare two dilbits on a wild-sourced fish. There were $2.8 \%$ and $70 \%$ successful hatches at the highest AWB WAF and CLB WAF treatments, respectively. However, TPAH content was higher in CLB WAF, measured at $11 \mu \mathrm{g} / \mathrm{L}$, than AWB WAF, measured at 5.3 $\mu \mathrm{g} / \mathrm{L}$. These results differ from previous studies of Japanese medaka by Madison et al. (2015; 2017) where toxicity was observed at lower concentrations of CLB than AWB. However, variability in the state of weathering can lead to increased mortality, as GOC (2013) found that the rate of evaporation for AWB was higher than for CLB. This study assesses the biomarkers that may be differentially affected by varied components in these two dilbits.

Malformations were present in AWB and CLB treatments. EC50s were estimated at 2.8 and $6.4 \mu \mathrm{g} / \mathrm{L}$ TPAH for AWB and CLB WAF, respectively. Thus, AWB WAF caused higher toxicity than CLB WAF at lower TPAH concentrations. However, in CEWAF treatments, the CLB EC50 was estimated at $18 \mu \mathrm{g} / \mathrm{L}$ TPAH, and less than $50 \%$ of fish responded to AWB, so that the EC50 was greater than the highest concentration tested (1.4 $\mu \mathrm{g} / \mathrm{L}$ TPAH). Previous studies have found that at equal measured TPAH $(\mu \mathrm{g} / \mathrm{L})$ concentrations of WAF and CEWAF, CEWAF treatments increase fish exposure to petroleum hydrocarbons, causing an apparent increase in toxicity (Adams et al. 2014b). However in this study, hatching success was lower and malformations were higher in WAF treatments at equivalent concentrations of TPAH.

In this study, AWB WAF exposures caused the lowest frequency of affected fish (one or more malformations), which may have occurred due to high mortality. Unlike previous studies with Japanese medaka, non-inflated swim bladders were not present as a malformation in yellow 
perch because swim bladder inflations take place within 1 week of hatching (Madison et al. 2015; 2017). Across all treatments, pericardial edema was the most frequently observed malformation that was present in at least $89 \%$ of affected fish in each treatment, and $90 \%$ of affected fish in the water control (Table 3). Tube heart was the next most frequent malformation, at a minimum of $25 \%$ of affected fish in every treatment. The prevalence of these malformations may be related, as there is a known relationship between cardiac dilation and subsequent stretching of the cardiac chambers with PAH exposure (Incardona et al. 2004). While Madison et al. (2017) associated cardiac abnormalities to CEWAF treatments, this experiment found contrasting effects. Both AWB and CLB WAF treatments caused a higher prevalence of cardiac effects than CEWAF. These results align with a higher proportion of affected fish in WAF treatments than in CEWAF.

It is well established that cardiac function is impeded by PAH exposure (Incardona et al. 2009; Incardona et al. 2015). Pericardial edema and tube heart cardiovascular malformations are caused by PAH exposure, which affects circulation and oxygen delivery (Alderman et al. 2017). Furthermore, exposure to Deepwater Horizon oil has caused atrial arrhythmias in pelagic fish species, although this oil is composed of a higher proportion of tricyclic PAHs and lower proportion of acutely lethal naphthalenes than dilbit (Incardona et al. 2014). Likewise, exposure to Deepwater Horizon crude oil decreased calcium current and calcium cycling, which interrupted excitation-contraction coupling in cardiac myocytes (Brette et al. 2014). These effects may continue into later life stages after chronic embryonic oil exposure by exhibiting changes in heart shape and reducing swimming performance (Hicken et al. 2011; Alderman et al. 2017). Thus, oil-exposed embryos that do not exhibit cardiac malformations may be affected later in life, causing overall population changes. 
Yellow perch exposed to both dilbits exhibited molecular responses to both WAF and CEWAF treatments, particularly for cyp $1 a$. The CYP family includes a number of heme proteins that are involved in the metabolism of drugs, environmental contaminants, steroids, prostaglandins, and fatty acids (Guengerich and Shimada 1991). Expression of cypla is a widely used biomarker for a variety of contaminants that has shown robust responses to PAH exposure of fish (Ramachandran et al. 2004; Madison et al. 2015, 2017; Alderman et al. 2017). Because increases in cyp la relative mRNA expression indicate petrogenic PAH accumulation, cypla functions as an ideal biomarker for oil exposure separate from environmental factors that affect PAH bioavailability (Madison et al. 2017). In this study, cypla mRNA levels were significantly increased in the highest WAF and CEWAF treatments. It is noteworthy that cypla was induced at lower TPAH concentrations in AWB than CLB. These results parallel the traditional toxicity results exhibited through hatching success and malformations in this study. However, while lower EC50s and proportions of cardiac malformations were seen in CEWAF treatments, cyp 1a inductions were higher than WAF treatments. Cypla mRNA levels were induced by up to 18fold in WAF treatments and up to 50-fold in CEWAF treatments. Maximal activity of CYP1A occurs after maximal expression of cypla mRNA in fish embryos (Lee et al. 2014). Thus, Madison et al. (2017) suggested that cypla mRNA is a more predictive biomarker of PAH toxicity than enzyme activity. Furthermore, cypla mRNA may be a precursor to dilbit toxicity before the responses are exhibited by malformations in CEWAF treatments. Transcripts of cypla mRNA are sensitive, and the maximum response is evident earlier than enzyme activity (Lee et al. 2014). While cypla and malformations responses of Japanese medaka have increased monotonically with oil exposure (Madison et al. 2017), this study found a higher \% affected and a smaller fold change for cypla mRNA in WAF treatments than CEWAF. Thus, larger cypla 
mRNA changes but fewer malformations were seen in yellow perch CEWAF treatments than WAF treatments, while AWB caused malformations and cypla induction at lower TPAH concentrations than CLB. In contrast, cardiotoxicity may be mediated by AhR2, a divergent and abundant AhR protein, and may be independent of CYP1A during exposure to retene, a 3-ringed alkyl PAH (Hahn 2002; Scott et al. 2011). Therefore, cardiac malformations in WAF treatments may be caused by different alkyl PAHs than cypla inducers in CEWAF treatments.

The expression of phase II or xenobiotic genes in dilbit-exposed yellow perch embryos was not comparable to relative changes for cypla mRNA. However, significant changes were observed for relative gsr mRNA induced up to 35-fold, but this trend was only seen in the highest AWB CEWAF treatment. There are a number of studies on developing fish that have found changes in gsr mRNA following PAH exposure (Goodale et al. 2015; Madison et al. 2015; Madison et al. 2017). However, few changes in gsr were statistically significant. One study on rainbow trout found that exposure to PCBs caused an increase in phase II enzyme and GSR activity (Förlin et al. 1996). Increased enzyme activity of GSR can occur during oxidative stress in littoral fish exposed to a number of environmental contaminants, such PCBs, metals, and PAHs; it was suggested that antioxidant activities acted as a protection mechanism during chronic oxidative stress (Rodriguez-Ariza et al. 1993). As the GSR enzyme replenishes GST levels and assists in the cellular production of ROS, it may also indicate the presence of higher concentrations of peroxidative elements (Stephensen et al. 2000). Thus, it may be valuable to assess propagation of lipid peroxidation in future studies.

Other phase II genes assessed in this study, such as cat and sod, exhibited responses to dilbit exposure. Relative mRNA levels in cat were upregulated similarly to gsr in the highest AWB CEWAF treatment, but only by 5-fold. Furthermore, sod transcripts were significantly 
increased when exposed to $0.25 \mu \mathrm{g} / \mathrm{L}$ TPAH of CLB WAF, and then decreased. As with upregulation of $g s r$, these significant changes suggest the production of ROS in yellow perch embryos through the conversion of superoxide $\left(\mathrm{O}_{2}{ }^{-}\right)$to hydrogen peroxide $\left(\mathrm{H}_{2} \mathrm{O}_{2}\right)$ by SOD, and then from $\mathrm{H}_{2} \mathrm{O}_{2}$ to $\mathrm{H}_{2} \mathrm{O}$ by CAT (Valavanidis et al. 2006). Madison et al. (2015) found significant increases for sod mRNA in Japanese medaka embryos exposed to AWB WAF and decreases in AWB CEWAF, although the treatment effect was not significant. Similarly, sod mRNA was significantly upregulated in AWB WAF treatments in this exposure. Fish acutely exposed to metal contaminants have displayed decreases in sod mRNA levels, indicating ROSinduced peroxidation (Zikić et al. 2001). These changes could be occurring in yellow perch embryos due to ROS production caused by exposure to dilbit. However, the induction of sod mRNA in this study is small in comparison to other genes of interest and remains inconclusive. Ahr expression was significantly increased at the highest AWB CEWAF treatment, similarly to gsr and cat. This trend was in contrast to studies on Japanese medaka where larger changes in gene expression were seen in AWB compared to CLB chronic exposure, which may be due to its higher concentration of PAHs (King et al. 2014; Madison et al. 2015). However, gene expression results align with EC50s determined in this study. The weathering state of AWB dilbit in comparison to CLB dilbit may cause different effects in yellow perch than Japanese medaka because of varied life history traits, as well as embryo size (surface area of membrane to volume ratio) or rearing temperature $\left(15^{\circ} \mathrm{C}\right.$ for yellow perch compared to $27^{\circ} \mathrm{C}$ in Japanese medaka). Unlike previous exposures, a significant relationship was determined between dilbit exposure to yellow perch and $a h r$ upregulation (Madison et al. 2015; Madison et al. 2017). The AhR response may parallel CYP1A responses during oil PAH exposure to Gulf killifish (Fundulus grandis; Whitehead et al. 2012). Post-translational phosphorylation of CYPs can 
affect CYP activity and affect nuclear localization of the AhR (Oesch-Bartlomowicz and Oesch 2005). However, this correlation was not evident in this study, emphasizing that PAHs are a classical ligand inducer of AhR translocation that may interfere with cAMP activation, which activates protein kinase A (Oesch-Bartlomowicz and Oesch 2005). Likewise, Incardona (2005) found that cardiotoxicity during exposure to weathered oil is caused by low-molecular weight PAHs and is AhR independent. AWB also contains a higher proportion of low-molecular weight compounds, including saturates and aromatics, than CLB (King et al. 2014). Therefore, these low-molecular weight compounds may be causing increased sublethal responses by other mechanisms than AhR binding.

Exposure mutations caused by cell cycling may be understood through the assessment of p53 (Williams and Hubberstey 2014). In this study, p53 relative mRNA was significantly increased with exposure to $0.25 \mu \mathrm{g} / \mathrm{L}$ TPAH of CLB WAF and $0.55 \mu \mathrm{g} / \mathrm{L}$ TPAH of AWB WAF treatments. When cells are exposed to ROS or hypoxia stress that damages DNA, p53 acts to promote cell survival or death (Graeber et al. 1996). These damaged cells may become permanently arrested for repair before the cell division phase (Evan and Littlewood 1998). Furthermore, Lesser et al. (2001) suggests that embryo development may be extended through DNA damage and cell cycle delays, causing smaller embryo size at hatch. However, these effects remain unclear in treatments where $p 53$ was elevated and cannot be verified by direct correlations to developmental delays.

Some results of this study are unexpected, particularly because AWB treatments exhibited toxicity at lower TPAH concentrations than CLB, and WAF was more toxic than CEWAF. These results may suggest that toxicity mechanisms are non-AhR dependent because malformations and gene expression did not align. Yellow perch embryos differ from species 
used in previous toxicity tests (Madison et al. 2015; 2017); their eggs are connected in a gelatinous, strand-like mass that is laid in ribbons. Yellow perch are the only known North American fish to produce a protective jelly coat, which may allow them to avoid intensive predation (Almeida et al. 2017). At lower volumes of dilbit, this jelly coat may protect yellow perch embryos from PAH absorption and reduce the bioavailability of these compounds. Furthermore, yellow perch could have low sensitivity to gene activation and the kinetics of uptake and distribution of PAH among tissues. Thus, yellow perch embryos could be among the most resilient North American fish species to dilbit exposure. This study could provide a baseline for oil-resistant freshwater fish species and emphasizes the necessity for further comparative studies of indigenous fish.

This study provides the first simultaneous assessment of the toxicity of two Canadian dilbits to a native Canadian fish species. With the recent approvals of pipeline projects throughout North America, it is critical that the effects of dilbit on resident fish species are understood. In this study, AWB caused higher toxicity compared to CLB, which contrasts previous studies on Japanese medaka (Madison et al. 2015; 2017). Thus, the effects of species differences require further investigation to determine the toxicity of various dilbits blends. Furthermore, genetic changes were larger and malformations were lower in CEWAF treatments than WAF treatments, which may suggest different mechanisms of cardiotoxicity and cypla induction. The molecular responses found in this study emphasize the importance of comparative studies to determine the toxicity of dilbit blends and the mechanisms of PAH toxicity in fish species in Canada. 


\section{REFERENCES}

Adams, J., Sweezey, M., Hodson, P.V., 2014a. Oil and oil dispersant do not cause synergistic toxicity to fish embryos. Environmental Toxicology and Chemistry 33, 107-114.

Adams, J., Bornstein, J.M., Munno, K., Hollebone, B., King, T., Brown, R.S., Hodson, P.V., 2014b. Identification of compounds in heavy fuel oil that are chronically toxic to rainbow trout embryos by effects-driven chemical fractionation. Environmental Toxicology and Chemistry 33(4), 825-835.

Alberta Energy, 2011. Alberta Energy: Facts and Statistics. Government of Alberta. $<$ http://www.energy.alberta.ca/OilSands/791.asp $>$ (Accessed February 2017).

Alderman, S.L., Lin, F., Farrell, A.P., Kennedy, C.J., Gillis, T.E., 2017. Effects of diluted bitumen exposure on juvenile sockeye salmon: From cells to performance. Environmental Toxicology and Chemistry 36(2), 354-360.

Almeida, L.Z., Guffey, S.C., Krieg, T.A., Höök, T.O., 2017. Predators Reject Yellow Perch Egg Skeins. Transactions of the American Fisheries Society 146(1), 173-180.

Balk, L., Hylland, K., Hansson, T., Berntssen, M.H., Beyer, J., Jonsson, G., Melbye, A., Grung, M., Torstensen, B.E., Børseth, J.F., Skarphedinsdottir, H., 2011. Biomarkers in natural fish populations indicate adverse biological effects of offshore oil production. PLoS One 6(5), e19735.

Barron, M. G., Podrabsky, T., Ogle, S., Ricker, R., 1999. Are aromatic hydrocarbons the primary determinant of petroleum toxicity to aquatic organisms? Aquatic Toxicology 46(3), 253-268.

Beland, F.A., Poirier, M.C., 1989. DNA adducts and carcinogenesis. Chapter 3 in The pathobiology of neoplasia, pp 57-80. New York, New York, Springer US.

Bornstein, J.M., Adams, J., Hollebone, B., King, T., Hodson, P.V., Brown, R.S., 2014. Effectsdriven chemical fractionation of heavy fuel oil to isolate compounds toxic to trout embryos. Environmental Toxicology and Chemistry 33(4), 814-824.

Brette, F., Machado, B., Cros, C., Incardona, J.P., Scholz, N.L., Block, B.A., 2014. Crude oil impairs cardiac excitation-contraction coupling in fish. Science 343, 772-776.

Brown, T.G., Runciman, B., Bradford, M.J., Pollard, S., 2009. A biological synopsis of yellow perch (Perca flavescens). Canadian Manuscript Report of Fisheries and Aquatic Sciences 2883, 28.

CAPP (Canadian Association of Petroleum Producers), 2014. Crude Oil: Forecast, Markets and Transportation. Canadian Association of Petroleum Producers. Calgary, Alberta.

Carls, M.G., Holland, L., Larsen, M., Collier, T.K., Scholz, N.L., Incardona, J.P., 2008. Fish embryos are damaged by dissolved PAHs, not oil particles. Aquatic Toxicology 88(2), 121-127.

Craig, J., 1987. Biology of perch and related fish. Croom Helm; Timber Press.

Crosby, S., Fay, R., Groark, C., Kani, A., Smith, J.R., Sullivan, T., 2013. Transporting Alberta oil sands products: defining the issues and assessing the risks, in: U.S.Department of Commerce, (Ed.). Emergency Response Division, NOAA, Seattle, WA, 153.

Dautremepuits, C., Marcogliese, D.J., Gendron, A.D., Fournier, M., 2009. Gill and head kidney antioxidant processes and innate immune system responses of yellow perch (Perca flavescens) exposed to different contaminants in the St. Lawrence River, Canada. Science of the Total Environment 407(3), 1055-1064. 
Dew, W.A., Hontela, A., Rood, S.B., Pyle, G.G., 2015. Biological effects and toxicity of diluted bitumen and its constituents in freshwater systems. Journal of Applied Toxicology 35(11), 1219-1227.

Di Giulio, R.T., Benson, W.H., Sanders, B.M., Van Veld, P.A., 1995. Biochemical mechanisms: metabolism, adaptation, and toxicity. Fundamentals of Aquatic Toxicology 2, 523e560.

Dupuis, A., Ucan-Marin, F., 2015. A literature review on the aquatic toxicology of petroleum oil: An overview of oil properties and effects to aquatic biota, Fisheries and Oceans Canada, Science Advisory Secretariate. Fisheries and Oceans Canada, Science Advisory Secretariate, Doc. 2015/007. Ottawa, ON, Canada, p. vi +52.

Environment Canada, 2006. Oil properties database. $<$ http://www.etccte.ec.gc.ca/databases/OilProperties/oil_prop_e.html> (Accessed February 2017).

Evan, G., Littlewood, T.,1998. A matter of life and cell death. Science 281(5381), 1317- 1322.

Fallahtafti, S., Rantanen, T., Brown, R.S., Snieckus, V., Hodson, P.V., 2012. Toxicity of hydroxylated alkyl-phenanthrenes to the early life stages of Japanese medaka (Oryzias latipes). Aquatic Toxicology 106-107, 56-64.

Farmer, P.B., Shuker, D.E.G., 1999. What is the significance of increases in background levels of carcinogen-derived protein and DNA adducts? Some considerations for incremental risk assessment. Mutation Research, Fundamental and Molecular Mechanisms of Mutagenesis 424, 275-286.

Fingas, M., 2015. Diluted bitumen (dilbit): A future high risk spilled material. Proceedings of Interspill. Edmonton, Alberta, Canada. Spill Science 24.

Förlin, L., Blom, S., Celander, M., Sturve, J., 1996. Effects on UDP glucuronosyl transferase, glutathione transferase, DT-diaphorase and glutathione reductase activities in rainbow trout liver after long-term exposure to PCB. Marine Environmental Research 42(1-4), 213-216.

Forney, J.L., 1974. Interactions between yellow perch abundance, walleye predation, and survival of alternate prey in Oneida Lake, New York. Transactions of the American Fisheries Society 103(1), 15-24.

French, B.L., Reichert, W.L., Hom, T., Nishimoto, M., Sanborn, H.R., Stein, J.E., 1996. Accumulation and dose-response of hepatic DNA adducts in English sole (Pleuronectes vetulus) exposed to a gradient of contaminated sediments. Aquatic Toxicology 36(1), 116.

George-Ares, A., Lessard, R. R., Canevari, G. P., Becker, K. W., Fiocco, R. J., 2001, March. Modification of the Dispersant Corexit ${ }^{\circledR} 9500$ for use in Freshwater. In International Oil Spill Conference, American Petroleum Institute 2001(2), 1209-1211.

GOC, 2013. Federal Government of Canada Technical Report: Properties, composition and marine spill behaviour, fate and transport of two diluted bitumen products from the Canadian oil sands. Government of Canada (GOC) Ottawa, 1-85.

Goksøyr, A., Husøy, A.M., 1998. Immunochemical approaches to studies of CYP1A localization and induction by xenobiotics in fish. Fish Ecotoxicology, Birkhäuser Basel, pp 165-202.

Goodale, B.C., La Du, J., Tilton, S.C., Sullivan, C.M., Bisson, W.H., Waters, K.M., Tanguay, R.L., 2015. Ligand-specific transcriptional mechanisms underlie aryl hydrocarbon receptor-mediated developmental toxicity of oxygenated PAHs. Toxicological Sciences, 147(2), 397-411. 
Graeber, T.G., Osmanian, C., Jacks, T., Housman, D.E., Koch, C.J., Lowe, S.W., Giaccia, A.J., 1996. Hypoxia-mediated selection of cells with diminished apoptotic potential in solid tumours. Nature 379(6560), 88-91.

Guengerich, F.P., Shimada, T., 1991. Oxidation of toxic and carcinogenic chemicals by human cytochrome P-450 enzymes. Chemical Research in Toxicology 4(4), 391-407.

Hahn, M.E., 2002. Aryl hydrocarbon receptors: diversity and evolution. Chemico-biological Interactions 141(1), 131-160.

Hawkins, S.A., Billiard, S.M., Tabash, S.P., Brown, R.S., Hodson, P.V., 2002. Altering cytochrome P4501A activity affects polycyclic aromatic hydrocarbon metabolism and toxicity in rainbow trout (Oncorhynchus mykiss). Environmental Toxicology and Chemistry 21(9), 1845-1853.

Hemmer, M.J., Barron, M.G., Greene, R.M., 2011. Comparative toxicity of eight oil dispersants, Louisiana sweet crude oil (LSC), and chemically dispersed LSC to two aquatic test species. Environmental Toxicology and Chemistry 30(10), 2244-2252.

Hicken, C.E., Linbo, T.L., Baldwin, D.H., Willis, M.L., Myers, M.S., Holland, L., Larsen, M., Stekoll, M.S., Rice, S.D., Collier, T.K., Scholz, N.L., 2011. Sublethal exposure to crude oil during embryonic development alters cardiac morphology and reduces aerobic capacity in adult fish. Proceedings of the National Academy of Sciences 108(17), 70867090.

Hodson, P.V., Khan, C.W., Saravanabhavan, G., Clarke, L., Brown, R.S., Hollebone, B., Wang, Z., Short, J., Lee, K., King, T., 2007. Alkyl PAH in crude oil cause chronic toxicity to early life stages of fish. Proceedings, 28th Arctic and Marine Oilspill Program Technical Seminar, Edmonton, AB, Canada, June 4-7, 2007, 291-300.

Incardona, J.P., Collier, T.K., Scholz, N.L., 2004. Defects in cardiac function precede morphological abnormalities in fish embryos exposed to polycyclic aromatic hydrocarbons. Toxicology and Applied Pharmacology 196(2), 191-205.

Incardona, J.P., Carls, M.G., Teraoka, H., Sloan, C.A., Collier, T.K., Scholz, N.L., 2005. Aryl hydrocarbon receptor-independent toxicity of weathered crude oil during fish development. Environmental Health Perspectives 113(12), 1755-1762.

Incardona, J.P., Carls, M.G., Day, H.L., Sloan, C.A., Bolton, J.L., Collier, T.K., Scholz, N.L., 2009. Cardiac arrhythmia is the primary response of embryonic Pacific herring (Clupea pallasi) exposed to crude oil during weathering. Environmental Science \& Technology 43, 201-207.

Incardona, J.P., Gardner, L.D., Linbo, T.L., Brown, T.L., Esbaugh, AJ., Mager, E. M., Stieglitz, J.D., French, B.L., Labenia, J.S., Laetz, C.A., Tagal, M., 2014. Deepwater Horizon crude oil impacts the developing hearts of large predatory pelagic fish. Proceedings of the National Academy of Sciences 111(15), E1510-E1518.

Incardona, J.P., Carls, M.G., Holland, L., Linbo, T.L., Baldwin, D.H., Myers, M.S., Peck, K.A., Tagal, M., Rice, S.D., Scholz, N.L., 2015. Very low embryonic crude oil exposures cause lasting cardiac defects in salmon and herring. Scientific Reports 5, 13499.

Kinder Morgan, 2016. Expansion project. <https://www.transmountain.com/expansion-project> (Accessed October 2016).

King, T.L., Robinson, B., Boufadel, M., Lee, K., 2014. Flume tank studies to elucidate the fate and behavior of diluted bitumen spilled at sea. Marine Pollution Bulletin 83, 32-37. 
King, T.L., Robinson, B., McIntyre, C., Toole, P., Ryan, S., Saleh, F., Boufadel, M.C., Lee, K., 2015. Fate of surface spills of Cold Lake blend diluted bitumen treated with dispersant and mineral fines in a wave tank. Environmental Engineering Science 32(3), 250-261.

Krieger, D.A., Terrell, J.W., Nelson, P.C., 1983. Habitat suitability information: yellow perch. US Fish and Wildlife Service. FWS/OBS-83/10.55.

Kujawinski, E.B., Kido Soule, M.C., Valentine, D.L., Boysen, A.K., Longnecker, K., Redmond, M.C., 2011. Fate of dispersants associated with the Deepwater Horizon oil spill. Environmental Science \& Technology 45(4), 1298-1306.

Lackner, R., 1998. Oxidative stress in fish by environmental pollutants. Fish Ecotoxicology 86, 203-224. Birkhäuser Basel.

Lawler, G.H., 1954. Observations on the trout-perch Percopsis omiscomaycus (Walbaum), at Heming Lake, Manitoba. Journal of the Fisheries Board of Canada 11(1), 1-4.

Lee, J.W., Kim, Y.H., Yoon, S., Lee, S.K., 2014. Cytochrome P450 system expression and DNA adduct formation in the liver of Zacco platypus following waterborne Benzo(a)pyrene exposure: implications for biomarker determination. Environmental Toxicology 29, 1032-1042.

Lee, K., Bugden, J., Cobanli, S., King, T., McIntyre, C., Robinson, B., Ryan, S., Wohlgeschaffen, G., 2012. UV-Epifluorescence Microscopy Analysis of Sediments Recovered from the Kalamazoo River, U.S. EPA Kalamazoo Administrative Recor d, document \#1277. <www.epa.gov/enbridgespill/ar/enbridge-AR-1277.pdf> (Accessed November 2013).

Lee, K., Boufadel, M., Chen, B., Foght, J., Hodson, P., Venosa, S.S.A., 2015. Expert panel report on the behaviour and environmental impacts of crude oil released into aqueous environments. Royal Society of Canada, Ottawa, Canada.

Lesser, M.P., Farrell, J.H., Walker, C.W., 2001. Oxidative stress, DNA damage and p53 expression in the larvae of Atlantic cod (Gadus morhua) exposed to ultraviolet (290-400 $\mathrm{nm}$ ) radiation. Journal of Experimental Biology 204(1), 157-164.

Ma, Q., 2001. Induction of CYP1A1. The AhR/DRE paradigm transcription, receptor regulation, and expanding biological roles. Current Drug Metabolism 2(2), 149-164.

Madison, B.N., Hodson, P.V., Langlois, V.S., 2015. Diluted bitumen causes deformities and molecular responses indicative of oxidative stress in Japanese medaka embryos. Aquatic Toxicology 165, 222- 230.

Madison, B.N., Hodson, P.V., Langlois, V.S., 2017. Cold Lake Blend diluted bitumen toxicity to the early development of Japanese medaka. Environmental Pollution, In press: http://dx.doi.org/10.1016/j.envpol.2017.03.025

Mangan, M.T., 2004. Yellow perch production and harvest strategies for semi-permanent wetlands in Eastern South Dakota. Doctoral dissertation, M. Sc. thesis, Wildlife and Fisheries Sciences, South Dakota State University. $<$ http://www3. sdstate. edu/wfs/publications/thesis/upload/Mangan-Matthew > (Accessed September 2016).

Marcogliese, D.J., Brambilla, L.G., Gagné, F., Gendron, A.D., 2005. Joint effects of parasitism and pollution on oxidative stress biomarkers in yellow perch Perca flavescens. Diseases of Aquatic Organisms 63(1), 77-84.

Martin, J.D., Colson, T.L.L., Langlois, V.S., Metcalfe, C.D., 2016. Biomarkers of exposure to nanosilver and silver accumulation in yellow perch (Perca flavescens). Environmental Toxicology and Chemistry. doi:10.1002/etc.3644 
Nebert, D. W., Dalton, T.P., Okey, A.B., Gonzalez, F.J., 2004. Role of aryl hydrocarbon receptor-mediated induction of the CYP1 enzymes in environmental toxicity and cancer. Journal of Biological Chemistry 279(23), 23847-23850.

Nielsen, L.A., 1980. Effect of walleye (Stizostedion vitreum vitreum) predation on juvenile mortality and recruitment of yellow perch (Perca flavescens) in Oneida Lake, New York. Canadian Journal of Fisheries and Aquatic Sciences 37(1), 11-19.

NRC (National Research Council), 2005. Oil Spill Dispersants: Efficacy and Effects; National Academy of Sciences.

NRC (National Research Council), 2013. Effects of diluted bitumen on crude oil transmission pipelines. TRB Special Report 311: National Academies Press, Washington, D.C. 93 p.

NRC (Natural Resources Canada), 2016. Oil Reserves. Natural Resources Canada. Energy. $<$ http://www.nrcan.gc.ca/energy/oil-sands/18085>

(Accessed February 2017).

Oesch-Bartlomowicz, B., Oesch, F., 2005. Phosphorylation of cytochromes P450: first discovery of a posttranslational modification of a drug-metabolizing enzyme. Biochemical and Biophysical Research Communications 338(1), 446-449.

Oris, J.T., Roberts, A.P., 2007. Statistical analysis of cytochrome P4501A biomarker measurements in fish. Environmental Toxicology and Chemistry 26(8), 1742-1750.

Philibert, D.A., Philibert, C.P., Lewis, C., Tierney, K.B., 2016. Comparison of diluted bitumen (dilbit) and conventional crude oil toxicity to developing zebrafish. Environmental Science \& Technology 50, 6091-6098.

Pierron, F., Bourret, V., St-Cyr, J., Campbell, P.G., Bernatchez, L., Couture, P., 2009. Transcriptional responses to environmental metal exposure in wild yellow perch (Perca flavescens) collected in lakes with differing environmental metal concentrations $(\mathrm{Cd}, \mathrm{Cu}$, Ni). Ecotoxicology 18(5), 620-631.

Place, B., Anderson, B., Mekebri, A., Furlong, E. T., Gray, J. L., Tjeerdema, R., Field, J., 2010. A role for analytical chemistry in advancing our understanding of the occurrence, fate, and effects of Corexit oil dispersants. Environmental Science and Technology 44(16), 6016-6018.

Posthuma, L., Suter, I.I. Traas, I.I, TP (Eds), 2002. Species Sensitivity Distributions in Ecotoxicology. Lewis Publishers: Boca Raton.

Prousek, J., 2007. Fenton chemistry in biology and medicine. Pure and Applied Chemistry 79(12), 2325-2338.

Ramachandran, S.D., Hodson, P.V., Khan, C.W., Lee, K., 2004. Oil dispersant increases PAH uptake by fish exposed to crude oil. Ecotoxicology and Environmental Safety 59(3), 300308.

Regoli, F., Giuliani, M.E., 2014. Oxidative pathways of chemical toxicity and oxidative stress biomarkers in marine organisms. Marine Environmental Research 93, 106-117.

Rodriguez-Ariza, A., Peinado, J., Pueyo, C., Lopez-Barea, J., 1993. Biochemical indicators of oxidative stress in fish from polluted littoral areas. Canadian Journal of Fisheries and Aquatic Sciences 50(12), 2568-2573.

Saravanabhavan G., 2007. An effect-driven fractionation approach for the isolation and characterization of CYP1A inducing components of crude oils. PhD thesis. Queen's University, Kingston, ON, Canada.

Scott, W.B., Crossman, E.J., 1973. Freshwater fishes of Canada. Fisheries Research Board of Canada Bulletin, 184. 
Scott, J.A., Incardona, J.P., Pelkki, K., Shepardson, S., Hodson, P.V., 2011. AhR2mediated, CYP1A-independent cardiovascular toxicity in zebrafish (Danio rerio) embryos exposed to retene. Aquatic Toxicology 101(1), 165-174.

Stephensen, E., Svavarsson, J., Sturve, J., Ericson, G., Adolfsson-Erici, M., Förlin, L., 2000. Biochemical indicators of pollution exposure in shorthorn sculpin (Myoxocephalus scorpius), caught in four harbours on the southwest coast of Iceland. Aquatic Toxicology 48(4), 431-442.

Timme-Laragy, A.R., Cockman, C.J., Matson, C.W., Di Giulio, R.T., 2007. Synergistic induction of AHR regulated genes in developmental toxicity from co-exposure to two model PAHs in zebrafish. Aquatic Toxicology 85(4), 241-250.

TransCanada, 2016. Energy East Pipeline Project. <http://www.transcanada.com/energy-eastpipeline.html $>$ (Accessed November 2016).

Trautman, M.B., 1957. The fishes of Ohio, Ohio State University Press, 1-683.

US EPA, 2013. Dredging Begins on Kalamazoo River: Enbridge Oil Marshall Michigan, $<$ www.epa.gov/enbridgespill/pdfs/enbridge_fs_201308.pdf > (Accessed October 2013).

Valavanidis, A., Vlahogianni, T., Dassenakis, M., Scoullos, M., 2006. Molecular biomarkers of oxidative stress in aquatic organisms in relation to toxic environmental pollutants. Ecotoxicology and Environmental Safety 64(2), 178-189.

Van der Oost, R., Beyer, J., Vermeulen, N.P., 2003. Fish bioaccumulation and biomarkers in environmental risk assessment: a review. Environmental Toxicology and Pharmacology 13(2), 57-149.

Wang, Z.D., Fingas, M., Page, D., 1999. Oil spill identification. Journal of Chromatography A 843, 369-411.

Wang, Z.D., Fingas, M., Blenkinsopp, S., Sergy, G., Landriault, M., Sigouin, L., 1998. Comparison of oil composition changes due to biodegradation and physical weathering in different oils. Journal of Chromatography A 809, 89-107.

Whitehead, A., Dubansky, B., Bodinier, C., Garcia, T.I., Miles, S., Pilley, C., Raghunathan, V., Roach, J.L., Walker, N., Walter, R.B., Rice, C.D., 2012. Genomic and physiological footprint of the Deepwater Horizon oil spill on resident marsh fishes. Proceedings of the National Academy of Sciences 109(50), 20298-20302.

Whiteside, M.C., Swindoll, C.M., Doolittle, W.L., 1985. Factors affecting the early life history of yellow perch, Perca flavescens. Environmental Biology of Fishes 12(1), 47-56.

Whyte, J.J., Jung, R.E., Schmitt, C.J., Tillitt, D.E., 2000. Ethoxyresorufin-O-deethylase (EROD) activity in fish as a biomarker of chemical exposure. Critical Reviews in Toxicology 30(4), 347-570.

Williams, R., Hubberstey, A.V., 2014. Benzo (a) pyrene exposure causes adaptive changes in p53 and CYP1A gene expression in Brown bullhead (Ameiurus nebulosus). Aquatic Toxicology 156, 201-210.

Yang, C., Wang, Z., Yang, Z., Hollebone, B., Brown, C.E., Landriault, M., Fieldhouse, B., 2011. Chemical fingerprints of Alberta oil sands and related petroleum products. Environmental Forensics 12(2), 173-188.

Yarranton, H.W., Okafor, J.C., Ortiz, D.P., van den Berg, F.G., 2015. Density and Refractive Index of Petroleum, Cuts, and Mixtures. Energy \& Fuels 29(9), 5723-5736.

Zikić, R.V., Stajn, A.S., Pavlović, S.Z., Ognjanović, B.I., Saićić, Z.S., 2001. Activities of superoxide dismutase and catalase in erythrocytes and plasma transaminases of goldfish 
(Carassius auratus gibelio Bloch.) exposed to cadmium. Physiology Research 50(1), 105-111.

\section{SUMMARY}

1. This study investigated the toxicity of AWB and CLB Canadian dilbits to developing yellow perch (Perca flavescens) embryos.

2. Because dilbit is a UCM with variable bitumen-to-diluent ratio and composition, it requires further research to understand the cellular mechanisms of components that are toxic to fish.

3. This study found that AWB had lower EC50s than CLB in yellow perch embryos.

4. The most prevalent malformations in both dilbits were pericardial edemas, then tube hearts.

5. The highest induction in relative mRNA was in cypla in all treatments, which was induced up to 18 -fold in WAF and 50-fold in CEWAF.

6. Other biomarkers including $a h r, g s r$, and cat, were significantly induced in the highest AWB CEWAF treatment.

7. However, sod and $p 53$ displayed significant differences in the second lowest concentration for CLB WAF and the middle AWB WAF concentration in $p 53$.

8. These results suggest that yellow perch embryos may be more resistant to oil PAH toxicity compared to Japanese medaka because of their distinct protective coating.

9. This study provides a unique comparison of the two most transported Canadian dilbits to an indigenous fish species, which offers a foundation for other comparative dilbit 


\section{APPENDIX}

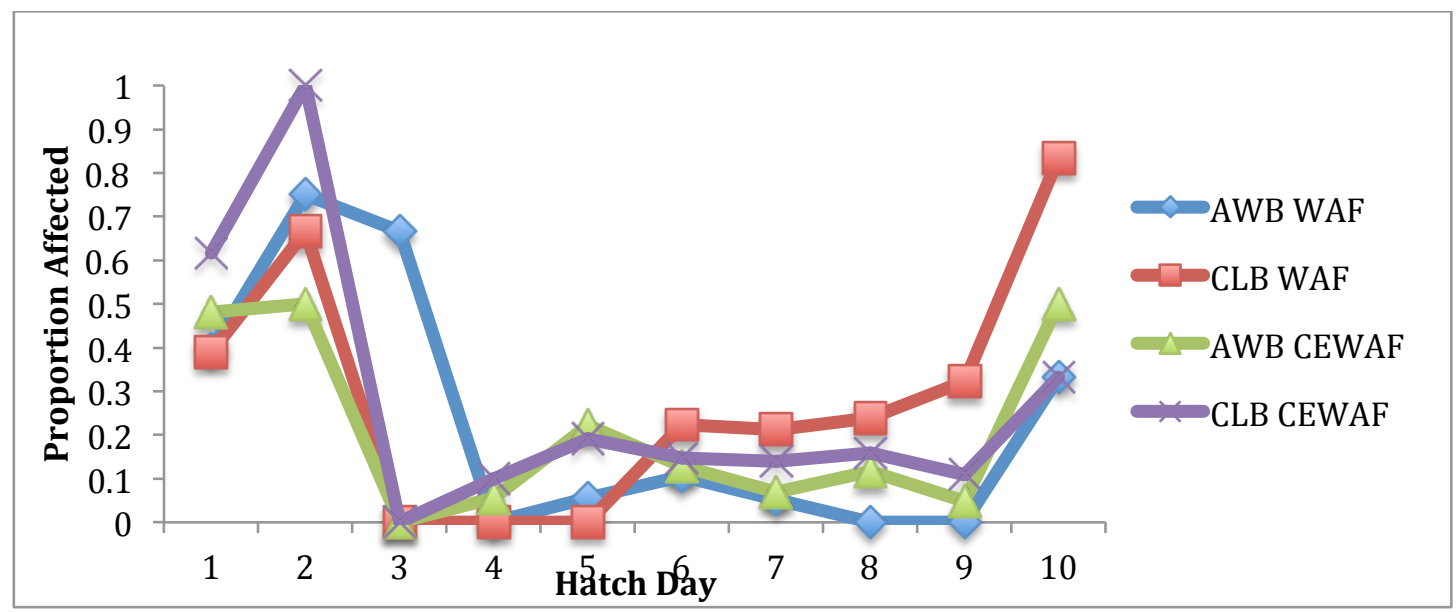

Figure S1. The proportion of dilbit exposed embryos that are affected on each day of hatch throughout the exposure (AWB WAF $\mathrm{n}=445$; CLB WAF $\mathrm{n}=530$; AWB CEWAF $\mathrm{n}=505$; CLB CEWAF $\mathrm{n}=530)$.

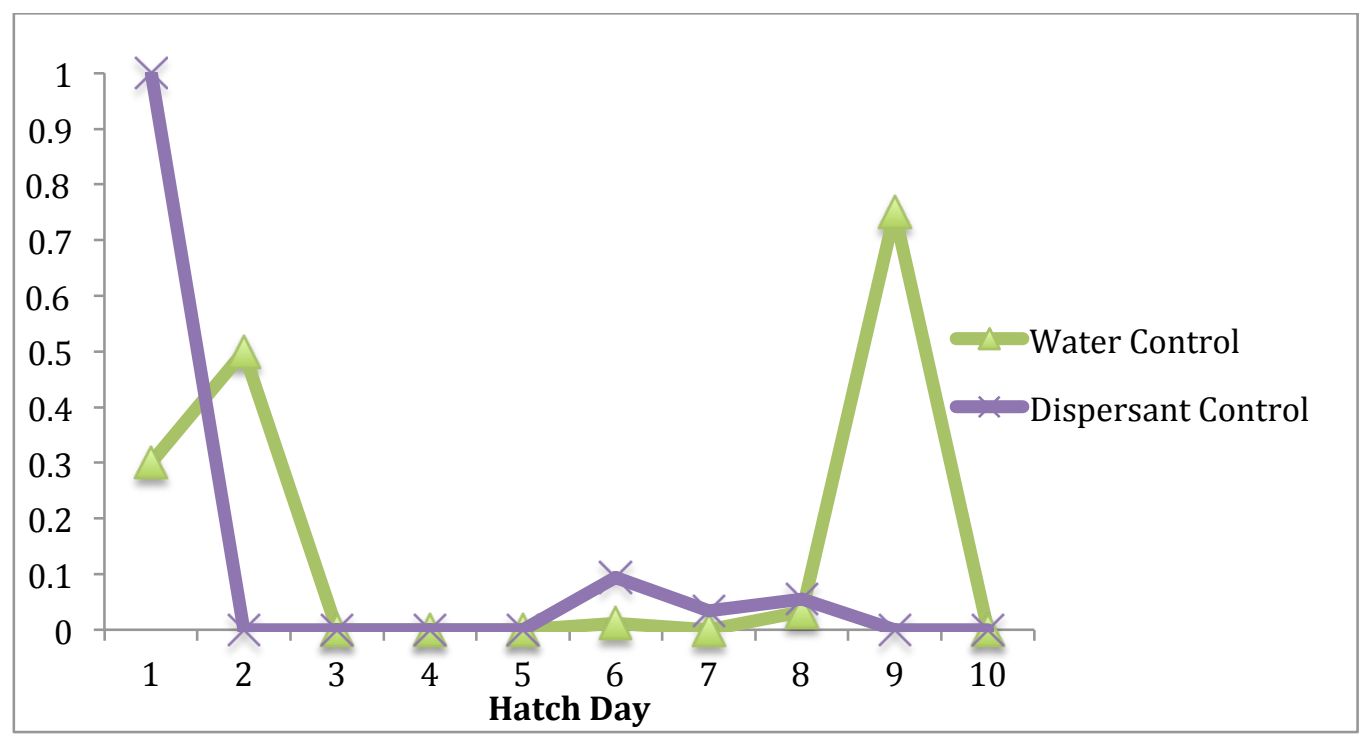

Figure S2. The proportion of control treatment embryos that are affected on each day of hatch throughout the exposure (Water control $n=261$; dispersant control $n=112$ ). 